\title{
The Spending and Debt Response to Minimum Wage Hikes
}

\author{
By Daniel Aaronson, Sumit Agarwal, and Eric French*
}

\begin{abstract}
Immediately following a minimum wage hike, household income rises on average by about $\$ 250$ per quarter and spending by roughly $\$ 700$ per quarter for households with minimum wage workers. Most of the spending response is caused by a small number of households who purchase vehicles. Furthermore, we find that the high spending levels are financed through increases in collateralized debt. Our results are consistent with a model where households can borrow against durables and face costs of adjusting their durables stock. (JEL D12, D14, D91, J38)
\end{abstract}

Many US social insurance programs provide economic assistance to low-income households. Yet there is little evidence on the spending response to income changes among such households. In this paper, we estimate the magnitude, composition, distribution, and timing of the income, spending, and debt responses to minimum wage hikes among households with adult minimum wage workers. We find that spending and debt rise substantially for a small set of these households following a minimum wage hike. These findings are consistent with a model where households can borrow against durables and face costs of adjusting their durables stock, suggesting that borrowing constraints and adjustment costs are important factors driving spending patterns among low-income households.

Using panel data from the Consumer Expenditure Survey (CEX), Survey of Income and Program Participation (SIPP), Current Population Survey (CPS), and administrative bank and credit bureau data, we identify households with adult minimum wage workers when the household is first observed. We then measure their spending, income, and debt before and after a minimum wage hike. Identification is based on a fixed effects procedure that compares households with minimum wage

\footnotetext{
*Aaronson: Federal Reserve Bank of Chicago, 230 South La Salle Street, Chicago, IL 60604 (e-mail: daaronson@frbchi.org); Agarwal: National University of Singapore, 15 Kent Ridge Drive, Singapore, 119245 (e-mail: ushakri@yahoo.com); French: Federal Reserve Bank of Chicago, 230 South La Salle Street, Chicago, IL 60604 (e-mail: efrench@frbchi.org). We thank Jeff Campbell, Chris Carroll, John Ham, Leslie McGranahan, Robert Moffitt, Victor Rios-Rull, Stephen Shore, Nick Souleles, Richard Spady, Irina Telyukova, Bill Wascher, Jim Ziliak, the referees, seminar participants at the Chicago Fed, Board of Governors, Federal Trade Commission, University of Illinois-Urbana Champaign, University of Alberta, Johns Hopkins, University of Maryland, Western Ontario, AEA, APPAM, and SED meetings, NBER Summer Institute, Micro and Macro Labor Market Models Conference at UCSB, and Jon Davis, Dan DiFranco, Phil Doctor, Charles Doss, Kyung Park, Shani Schechter, and Zach Seeskin for outstanding assistance. The views expressed in this paper do not necessarily reflect those of the Federal Reserve Bank of Chicago or the Federal Reserve System.

${ }^{\dagger}$ To view additional materials, visit the article page at http://dx.doi.org/10.1257/aer.102.7.3111.
} 
workers in states that experience a minimum wage increase to similar households in states that do not.

We present four key empirical findings. First, a \$1 minimum wage hike increases household income by roughly $\$ 250$ and spending by approximately $\$ 700$ per quarter (in 2005 dollars) in the year following a minimum wage hike. These findings are corroborated by independent data showing that debt rises substantially after a minimum wage increase. Second, the majority of this additional spending comes from a small number of households purchasing debt-financed new vehicles. $\square^{1}$ Third, total spending increases within one quarter of a minimum wage increase and not prior, despite legislation typically passing 6 to 18 months before enactment. Finally, high levels of durables spending and debt accumulation persist for several quarters after a minimum wage hike. These results are robust to changes in sample selection criteria and covariates. Furthermore, we find that a minimum wage hike has no income or spending effect on households with workers earning at least double the minimum wage, providing further evidence that our estimates are not the result of omitted variables.

We consider whether various permutations of the life-cycle model can fit the facts above. Two canonical models - the permanent income model and the buffer stock model with no borrowing - fail to do so. If households were spreading an income gain over their lifetime, as in the permanent income hypothesis, the short-run spending increase should be much smaller than what we observe in the data. Augmenting the permanent income model to account for durables raises the predicted short-term spending response. It is still an order of magnitude smaller than what our empirical estimates imply, however. Moreover, a buffer stock model in which households cannot borrow against durable goods generates a spending response of approximately $\$ 200$ and fails to explain why some minimum wage households increase their debt after a minimum wage hike.

Next, we consider an augmented buffer stock model in which households are collateral constrained-i.e., they can borrow against part, but not all, of the value of their durable goods. If households face collateral constraints, small income increases can generate small down payments, which in turn can be used for large durable goods purchases. With a 40 percent down payment, each additional dollar of income can be used to purchase $\frac{1}{0.4}=\$ 2.50$ of durable goods.

While this model fits the data better than the others, it still underpredicts the total spending response. Furthermore, it does not match the highly concentrated distribution of additional spending. Augmenting the model to allow for a cost of adjusting durables better replicates the skewness of the spending responses, but produces a smaller mean spending response. Assuming more widespread borrowing

\footnotetext{
${ }^{1} \mathrm{~A}$ large response in durables spending is consistent with many papers that focus on sizable disposable income changes, including those based on tax refunds (Parker 1999, Souleles 1999, and Parker et al. 2010), the Earned Income Tax Credit (EITC) (Barrow and McGranahan 2000; Adams, Einav, and Levin 2009), job loss (Browning and Crossley 2009), expansions in public health insurance programs (Leininger, Levy, and Schanzenbach 2010), and other large income changes (Krueger and Perri 2008). Moreover, Adams, Einav, and Levin (2009); Souleles (1999); Leininger, Levy, and Schanzenbach (2010); and Parker et al. (2010) also find evidence that much of this additional durable spending is on vehicles. Other papers find no response in durable spending (e.g., Browning and Collado 2001, and Hsieh 2003) or a highly imprecise response (e.g., Coulibaly and Li 2006). Our reading of the literature is that positive effects tend to be found in papers based on large income gains among more liquidity constrained households.
} 
constraints among minimum wage households, the model generates an almost $\$ 700$ spending response.

Models where households can borrow against durable goods are increasingly common for understanding the dynamics of consumer durables (Fernandez-Villaverde and Krueger 2011, Campbell and Hercowitz 2003), housing (Carroll and Dunn 1997; Attanasio, Leicester, and Wakefield 2011; Hryshko, Luengo-Prado, and Sorensen 2010; Cerletti and Pijoan-Mas 2012), and entrepreneurship (Kaboski and Townsend 2011). There is little direct micro evidence, however, on the quantitative importance of the constraint. Our paper provides such evidence.

In the aggregate, the spending effect that we estimate is nontrivial. For example, CPS data show that 7.3 million households earned at least 20 percent of total household income from adult minimum wage earnings in 2006. Our estimated $\$ 700$ average quarterly spending response thus translates into an additional $\$ 5$ billion $(=7.3$ million $\times \$ 700)$ in spending per quarter in the year following the hike. That said, this simple calculation likely overstates the true aggregate response. First, our estimates apply to households with a minimum wage worker prior to an increase in the minimum wage. It is possible that raising the minimum wage reduces the odds that those without a job will find one. Second, we ignore most teenagers, who comprise 29 percent of all minimum wage workers. There is stronger evidence of disemployment effects for teenagers than adults. Finally, minimum wage hikes cause prices of goods produced by minimum wage workers to rise (Aaronson 2001; Aaronson, French, and MacDonald 2008). Thus, real income and spending by nonminimum wage workers will likely fall. For those adults who had a minimum wage job prior to a minimum wage hike, however, spending (particularly on vehicles), income, and debt rise afterward.

The rest of the paper is organized as follows. Section I provides a brief description of the CEX, SIPP, CPS, and administrative bank and credit bureau datasets used to estimate the spending, income, and debt responses. Section II describes the empirical results. Section III outlines a calibrated model of household spending responses to a minimum wage increase when borrowing constraints are present versus absent and links these results to the empirical findings. Section IV concludes.

\section{Data}

This section describes the data that we use to measure income, wages, spending, and debt. Online Appendix A and online Appendix Table A1 provide additional description of the data and sample selection criteria. All nominal values are reported in 2005 dollars.

Our empirical analysis draws heavily from the CEX, a representative sample of US consumer units providing detailed information on household spending. ${ }^{2}$ The surveys span 1982 through 2008, a period in which six federal and numerous state minimum wage increases were enacted. The CEX interviews households up to five times, spaced three months apart. In each interview after the first, households are asked about detailed spending patterns for the previous three months. While this

\footnotetext{
${ }^{2}$ For ease of exposition, we refer to consumer units as households.
} 
design provides monthly data, we follow Johnson, Parker, and Souleles (2006) and aggregate to the quarterly frequency.

In the second and fifth interviews, households are also asked about each member's income and hours worked over the previous year. This information is used to calculate the hourly wage of the first two adult (older than 18) members of the household, which is compared to the state's effective minimum wage to identify minimum wage workers and households. After sample restrictions described in online Appendix A, we are left with 200,549 household-survey observations on spending, of which 11 percent derive some income from minimum wage work.

Two additional datasets - the 1983 to 2007 SIPP and the 1980 to 2007 outgoing rotation files of the CPS - are used to measure income patterns following a minimum wage increase. We show these results because of the larger samples $(809,631$ and 474,758 observations for the CPS and SIPP, respectively) and because each are designed specifically to measure higher frequency earnings and wages. For the purpose of identifying minimum wage workers, it is particularly useful that both surveys report the hourly wage of those paid by the hour. SIPP and CPS variables are coded, and wage, self-employment, and family composition restrictions are introduced, to be as close as possible to the CEX sample.

Finally, to verify the spending patterns documented in the CEX, we use a proprietary dataset from a large, national financial institution that issues credit cards. This institution merges in quarterly credit bureau reports about each credit card holder's auto, home equity, mortgage, and credit card balance to her credit card account. We draw two samples from this data: a $2 \frac{1}{2}$ year overlapping panel containing 4,610,497 observations from 1995 to 2008 and a separate sample of 644,037 observations that begins in January 2000 and runs for 4 years. This is not a random sample of households since an individual needs a credit card to be in this dataset: see online Appendix A.

We obtained state minimum wage histories from the January issues of the Monthly Labor Review. See online Appendix Table A2 for a list of minimum wage levels by year and state. ${ }^{\beta}$

\section{Empirical Results}

\section{A. Estimating Equations}

Our empirical strategy is standard. We estimate equations of the form

$$
z_{i t}=f_{i}+\sum_{k=-K}^{K} \phi_{k} w_{\min , i t+k}+\omega^{\prime} \mathbf{x}_{i t}+u_{i t}
$$

where $z_{i t}$ is either income (estimated from the CEX, CPS, and SIPP), spending (estimated from the CEX), or change in debt (estimated from the credit bureau data), and $w_{\min , \bar{l}+k}$ is the minimum wage rate for the state that individual $i$ resides in at time $t+k ; \mathbf{x}_{i t}$ includes year and quarter dummies or month dummies, and $f_{i}$ is

\footnotetext{
${ }^{3}$ We do not account for within-state differences in the minimum wage (i.e., the living wage initiatives that sprung up in a few cities during the 2000s).

${ }^{4}$ When using quarterly CEX and debt data, $w_{\min , i t+k}$ is the average value of the minimum wage over the quarter.
} 
a household fixed effect. 5 The $\phi_{k}$ parameters are separately identified from the time dummies and household fixed effects because many states raise the minimum wage above the federal minimum. Thus, we can control for time effects, and in so doing, the possibility that both the minimum wage and household spending rise in response to strong aggregate income growth.

Equation (1) is estimated separately for minimum wage and nonminimum wage households. In particular, let $S_{i}$ be the share of total household income that is derived from adults earning 60-120 percent of the minimum wage:

$$
S_{i}=\left(E_{1 i} \times I\left\{0.6 w_{\min , i} \leq w_{1 i} \leq 1.2 w_{\min , i}\right\}+E_{2 i} \times I\left\{0.6 w_{\min , i} \leq w_{2 i} \leq 1.2 w_{\min , i}\right\}\right) / F_{i},
$$

where $E_{1 i}$ and $E_{2 i}$ are the salary income for persons 1 and 2 (typically, the head and spouse), $F_{i}$ is total pretax nonasset income, and $I\left\{0.6 w_{\min , i} \leq w_{1 i} \leq 1.2 w_{\min , i}\right\}$ and $I\left\{0.6 w_{\min , i} \leq w_{2 i} \leq 1.2 w_{\min , i}\right\}$ are indicators of whether persons 1 and 2 earn between 60 and 120 percent of the minimum wage, all measured in the first period the household is observed. ${ }^{6}$

We report estimates of $\phi_{k}$ for households with no initial minimum wage earnings $\left(S_{i}=0\right)$, households with any adult minimum wage earnings $\left(S_{i}>0\right)$, and households with at least 20 percent of total income from adult minimum wage earnings $\left(S_{i} \geq 0.2\right)$. The latter highlights those households that rely more extensively on minimum wage income. 7

The credit bureau data contain the self-reported annual earnings of the account holder at the time of the credit card application but not hours worked necessary to construct $S_{i}{ }^{8}$ Therefore, the debt regressions weight the minimum wage variable $w_{\min , i t+k}$ in equation (1) by the probability that the holder is a minimum wage worker, $P_{i}$. In other words, we assume spending is as in equation (1) with probability $P_{i}$ and is equal to $f_{i}+\omega^{\prime} \mathbf{x}_{i t}+u_{i t}$ with probability $\left(1-P_{i}\right)$, which gives rise to the following regression:

$$
z_{i t}=f_{i}+\sum_{k=-K}^{K} P_{i} \phi_{k} w_{\min , i t+k}+\omega^{\prime} \mathbf{x}_{i t}+u_{i t} .
$$

To compute the weights, we use the CPS to estimate a probit model of whether a nonself-employed worker was within 120 percent of the minimum wage. Covariates are a quartic in annual earnings, a quartic in age, an age times annual earnings quartic, female, married, and female times married. The estimated probit model reveals that just under 60 percent of all individuals earning $\$ 10,000$ per year are minimum wage

\footnotetext{
${ }^{5}$ When available, we also condition on the number of adults and the number of kids in the household in order to be consistent with other research (e.g., Johnson, Parker, and Souleles 2006). Once the household fixed effect and time dummies are included, however, we find no observable covariates in the CEX or the debt data that substantively impact our coefficient of interest, $\phi_{k}$.

${ }^{6}$ Previous research (e.g., Card and Krueger 1995, Wellington 1991, Lee 1999) has shown that minimum wage hikes increase the wages of workers that make slightly above the minimum wage. Thus, we assume that those earning up to 120 percent of the minimum wage are impacted by the minimum wage, but the results are not sensitive to other reasonable values.

${ }^{7}$ Results are not sensitive to other reasonable $S_{i}$ thresholds, such as 10 and 30 percent.

${ }^{8}$ Technically, we only have information for individual card-holders, not the unit of interest, the household. We partially circumvent this limitation since debt contracts are typically written at the household level. Therefore, the credit bureau data are often, but not always, at the household level.
} 
Table 1-Total Household Nonproperty Quarterly Income Response to Change in the Minimum Wage

\begin{tabular}{|c|c|c|c|c|c|c|c|c|}
\hline \multirow{2}{*}{$\begin{array}{l}\text { Share of income } \\
\text { from minimum } \\
\text { wage jobs }\left(S_{i}\right)\end{array}$} & \multirow[b]{2}{*}{$\begin{array}{c}\text { CEX } \\
(1)\end{array}$} & \multirow[b]{2}{*}{$\begin{array}{l}\text { CPS } \\
(2)\end{array}$} & \multirow[b]{2}{*}{$\begin{array}{l}\text { SIPP } \\
(3)\end{array}$} & \multirow[b]{2}{*}{$\begin{array}{l}\text { Weighted } \\
\text { average }^{\mathrm{a}} \\
\text { (4) }\end{array}$} & \multicolumn{4}{|c|}{$\begin{array}{c}\text { "Minimum wage" worker }=120 \text { to } 300 \% \\
\text { of minimum }\end{array}$} \\
\hline & & & & & $\begin{array}{c}\text { CEX } \\
(5)\end{array}$ & $\begin{array}{l}\text { CPS } \\
(6)\end{array}$ & $\begin{array}{l}\text { SIPP } \\
(7)\end{array}$ & $\begin{array}{l}\text { Weighted } \\
\text { average }^{\mathrm{a}} \\
(8)\end{array}$ \\
\hline 0 & $\begin{array}{c}-83 \\
(233) \\
92,810\end{array}$ & $\begin{array}{c}-29 \\
(42) \\
688,356\end{array}$ & $\begin{array}{c}118 \\
(63) \\
420,634\end{array}$ & $\begin{array}{c}14 \\
(35)\end{array}$ & $\begin{array}{c}-54 \\
(432) \\
37,997\end{array}$ & $\begin{array}{c}55 \\
(98) \\
153,340\end{array}$ & $\begin{array}{c}-12 \\
(130) \\
112,022\end{array}$ & $\begin{array}{c}28 \\
(77)\end{array}$ \\
\hline$>0$ & $\begin{array}{c}247 \\
(399) \\
11,978\end{array}$ & $\begin{array}{c}276 \\
(102) \\
121,275\end{array}$ & $\begin{array}{c}178 \\
(138) \\
54,124\end{array}$ & $\begin{array}{l}242 \\
(80)\end{array}$ & $\begin{array}{c}-86 \\
(237) \\
54,813\end{array}$ & $\begin{array}{c}15 \\
(45) \\
535,016\end{array}$ & $\begin{array}{c}181 \\
(72) \\
308,612\end{array}$ & $\begin{array}{c}58 \\
(38)\end{array}$ \\
\hline$\geq 0.2$ & $\begin{array}{c}-138 \\
(450) \\
8,511\end{array}$ & $\begin{array}{c}247 \\
(105) \\
93,846\end{array}$ & $\begin{array}{c}254 \\
(129) \\
39,472\end{array}$ & $\begin{array}{l}237 \\
(80)\end{array}$ & $\begin{array}{c}-170 \\
(222) \\
50,102\end{array}$ & $\begin{array}{c}8 \\
(44) \\
501,925\end{array}$ & $\begin{array}{c}200 \\
(76) \\
276,213\end{array}$ & $\begin{array}{c}50 \\
(38)\end{array}$ \\
\hline Time period & 1983-2008 & 1980-2007 & 1986-2007 & & $1983-2008$ & 1980-2007 & 1986-2007 & \\
\hline Sample of workers ${ }^{c}$ & All & $\begin{array}{l}\text { Hourly wage } \\
\text { workers }\end{array}$ & $\begin{array}{l}\text { Hourly wage } \\
\text { workers }\end{array}$ & & All & $\begin{array}{l}\text { Hourly wage } \\
\text { workers }\end{array}$ & $\begin{array}{l}\text { Hourly wage } \\
\text { workers }\end{array}$ & \\
\hline
\end{tabular}

Notes: Each cell represents a separate regression; $S_{i}$ is the share of pretax total household income from near minimum wage salaries earned by the top two adults in the household. See the text for additional details. All standard errors are cluster corrected by household (consumer unit in CEX).

${ }^{\mathrm{a}}$ The weighted average estimate uses a GMM formula where weights are based on the precision of the individual estimates.

${ }^{\mathrm{b}}$ Columns 5 to 8 show the "minimum wage effect" for workers that are between 120 and 300 percent of the minimum wage. These regressions drop households with workers that are 120 percent or less (i.e. $S_{i}>0$ in columns 1 to 3) of the minimum wage.

${ }^{\mathrm{c}}$ The CEX sample includes all workers and is based on a computed wage equal to annual earnings divided by annual hours worked. The SIPP and CPS samples consist of households with a worker who is paid by the hour.

workers, whereas only 6 percent of individuals earning over $\$ 20,000$ per year are minimum wage workers. We therefore present the results separately for individuals whose earnings at credit card application are above and below \$20,000.

\section{B. The Magnitude of the Income Response}

Table 1 begins by documenting the impact of a $\$ 1$ increase in the minimum wage on household income. In these initial results, we ignore dynamics and set $K=0$ in equation (1). 9 Each cell in the table represents a different regression. The top number is the point estimate, the second number is the standard error corrected for within-household serial correlation, and the third is the sample size. Rows are organized by $S_{i}$, the share of household head and spouse earnings that come from employment at minimum wage jobs as measured at the time the household enters the survey. Thus, the first row includes households with no initial minimum wage income $\left(S_{i}=0\right)$ and the next two include households where total household income includes any $\left(S_{i}>0\right)$ or at least 20 percent $\left(S_{i} \geq 0.2\right)$ adult minimum wage earnings.

Column 1, based on the CEX, shows that a $\$ 1$ increase in the minimum wage causes after-tax income to rise among $S_{i}>0$ households. ${ }^{10}$ In contrast, there is

\footnotetext{
${ }^{9} \mathrm{~A}$ handful of studies have estimated similar income equations. Recent examples include Draca, Machin, and Van Reenen (2011); Addison, Blackburn, and Cotti (2008); and Neumark, Schweitzer, and Wascher (2004, 2005). Each of these studies finds evidence that minimum wage hikes increase household income in the short run.

${ }^{10}$ The after-tax income measure is based on self-reported federal, state, and local, and other taxes paid. It does not include payroll taxes.
} 
no income increase among households without minimum wage income. Precision is very low, however, and consequently the estimates among the minimum wage households are not stable across different $S_{i}$ thresholds. Indeed, the point estimate on $S_{i} \geq 0.2$ households is negative, albeit with a standard error four times as large. ${ }^{11}$

Therefore, the next two columns provide estimates from the CPS and SIPP. ${ }^{12}$ For households with at least 20 percent minimum wage income, we find that quarterly earnings rise by $\$ 247$ (\$105) and \$254 (\$129) in the CPS and SIPP immediately after a $\$ 1$ minimum wage increase. The final column reports a weighted average income response, where the weights are based on the precision of the three individual estimates. These calculations suggest that, in the near term, $S_{i}>0$ and $S_{i} \geq 0.2$ household quarterly income rises by roughly $\$ 240$ with a standard error, calculated using standard generalized method of moments (GMM) formulas, of $\$ 80 .{ }^{13}$

By comparison, the effect on nonminimum wage households is not statistically different from 0 (\$14 with a standard error of $\$ 35)$, suggesting the impact of the minimum wage law is limited to households with workers very close to their state's effective minimum wage. That is also the case when, as a finer test, we look at households near the minimum wage but not necessarily directly impacted by the law. Columns 5 to 8 define $S_{i}$ as the share of income earned by adult workers with a wage between 120 and 300 percent of the minimum wage. ${ }^{14}$

For households with such earners, we find no evidence of an income gain after a minimum wage increase in the CEX and CPS, although we observe a notable gain in the SIPP. A weighted average of the three datasets suggests the income gain is economically small and statistically indistinguishable both from zero and from the near zero gain among those with hourly wages more than triple the minimum (column 8, row 1). Moreover, the SIPP income gain is concentrated in households earning 120 to 200 percent of the minimum wage. Excluding these SIPP households that might plausibly be contaminated by the minimum wage law change (e.g., Card and Krueger 1995, Wellington 1991, Lee 1999), the estimated (but unreported) income gain among 200 to 300 percent households is \$28 (\$89) and the weighted average among the three datasets is $\$ 7$ (\$54).

It is important to note that household income need not rise among minimum wage workers if the legislated minimum wage increase leads to enough job loss. That does not appear to be the case, however. In online Appendix Table A3, we show that employment and hours do not fall after a minimum wage increase among our samples of adult CPS workers. Rather, wages rise among workers in minimum wage

\footnotetext{
${ }^{11}$ Reasonable alternative wage restrictions, such as dropping the top and bottom 1 percent, or not including a wage restriction results in positive point estimates.

${ }^{12}$ Unlike the CEX, these samples are restricted to households with hourly workers. As expected, when we use a computed wage, we find smaller earnings responses. The CPS and SIPP earnings measures are also pretax. In the CEX, we found the tax adjustment makes little difference to our estimates.

${ }^{13}$ An alternative way to compute the weighted average estimate is through a pooled regression with all three datasets with a full set of survey $\times$ covariate interactions. While there are important differences between the datasets (e.g., earnings refers to the previous year in the CEX but to the previous month in the CPS), we get similar results to column 4. For $S_{i}=0$ households, the pooled estimate is $\$ 60(\$ 42)$. For $S_{i} \geq 0.2$ households, the pooled estimate is $\$ 245(\$ 90)$.

${ }^{14}$ These samples exclude households with an adult worker within 120 percent of the minimum. That is, they only include the $S_{i}=0$ households from columns 1 to 3 , thereby comparing households with workers paid 120 to 300 percent of the minimum to those households where the adult workers earn over 300 percent of the minimum.
} 
households and not among nonminimum wage households, explaining the majority of the earnings pattern in Table 1.15

Beyond the first few quarters, the long-run effect of the minimum wage on income is more difficult to measure with existing data. Neumark, Schweitzer, and Wascher $(2004,2005)$ find that any income gain from a minimum wage increase dissipates substantially, perhaps even evaporates, within two years. This result is consistent with the empirical finding that many individuals who earn the minimum wage at a point in time will earn well above the minimum wage two years later (Smith and Vavrichek 1992; Carrington and Fallick 2001). Indeed, we find that only 64 percent (53 percent) of SIPP workers who make between 60 and 120 percent of their state's effective minimum wage are still within that range one (two) years later.

\section{The Magnitude of the Total Spending Response}

Table 2 reports the size of the spending response to a minimum wage increase. Like Table 1, each cell represents a separate regression and rows are stratified by $S_{i}$, the share of household income from minimum wage jobs.

Column 1 shows that total spending increases by an economically important and usually statistically significant amount for minimum wage households. Among households where minimum wage labor is the source of at least 20 percent of household income, total spending rises by $\$ 815$ (standard error of $\$ 457$ ) per quarter, representing 13 percent of an average quarter's spending (column 6). ${ }^{16}$ In contrast, spending among households without minimum wage workers does not respond to a minimum wage change ( $-\$ 57$ with a standard error of $\$ 150)$. Moreover, the spending response, like the income response reported in Table 1, is not statistically different from 0 among households with workers that are 120 to 300 percent above the minimum wage (column 2, rows 2 and 3). This finding confirms that the spending effect is likely caused by the minimum wage and not by state-specific unobservable trends in consumption that are specific to low-wage families.

This basic pattern is robust to many perturbations of the sample and the statistical model. In column 3, we show that the spending response is large for households that might be particularly liquidity constrained. Liquidity constraints are proxied, as in Johnson, Parker, and Souleles (2006), by whether a household's balance in checking and savings accounts is below $\$ 5,000$. The results are also strongest in states that instituted substantial hikes (column 4 versus 5). ${ }^{17}$ More generally, we find similar estimates when we remove data restrictions on family composition, age, wage levels, and wage changes, or control for other factors in the regressions, such as statespecific time trends, the age of the head, interview fixed effects, and changes to other

\footnotetext{
${ }^{15}$ Among $S_{i}>0$ households, average wages rise by roughly $\$ 0.47$ per hour. Household hours worked per week average about 50 . That implies roughly a $\$ 300$ increase in quarterly earnings $(0.47 \times 50 \times 13$ weeks $)$. There is also a small, positive hours impact of about one hour per week, mostly driven by spouses that would add roughly $\$ 50$ in earnings per quarter at the average minimum wage over this period.

${ }^{16}$ We also estimated a version of equation (1) in first differences. For $S_{i} \geq 0.2$ households, total spending increases by $\$ 658(\$ 522)$ in the quarter of the minimum wage increase. For $S_{i}=0$ households, the total spending effect is $\$ 23(\$ 180)$.

${ }^{17}$ We reestimated the model with a dummy for whether the minimum wage change was "small" and an interaction between this small indicator and the minimum wage. Small increases include years when a minimum wage increase was less than 25 cents or automated by CPI adjustments.
} 
Table 2-Total Spending Response to Change in the Minimum Wage: CEX, 1983-2008

\begin{tabular}{|c|c|c|c|c|c|c|c|}
\hline \multirow{2}{*}{$\begin{array}{l}\text { Share of } \\
\text { income from } \\
\text { minimum } \\
\text { wage jobs }\left(S_{i}\right)\end{array}$} & \multirow[b]{2}{*}{$\begin{array}{c}\text { Baseline } \\
\text { estimates } \\
\text { (1) }\end{array}$} & \multirow{2}{*}{$\begin{array}{l}120-300 \% \\
\text { of minimum } \\
\text { wage }^{\mathrm{a}} \\
(2)\end{array}$} & \multirow[b]{2}{*}{ 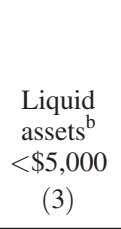 } & \multicolumn{2}{|c|}{ Size of increase ${ }^{c}$} & \multirow{2}{*}{$\begin{array}{c}\text { Real } \\
\text { average } \\
\text { quarterly } \\
\text { spending } \\
(6)\end{array}$} & \multirow{2}{*}{$\begin{array}{l}\text { Implied marginal } \\
\text { propensity to } \\
\text { spend using } \\
\text { average income } \\
\text { (7) }\end{array}$} \\
\hline & & & & $\begin{array}{c}\text { Small } \\
(4)\end{array}$ & $\begin{array}{l}\text { Large } \\
(5)\end{array}$ & & \\
\hline 0 & $\begin{array}{c}-57 \\
(150) \\
178,075\end{array}$ & $\begin{array}{c}67 \\
(252) \\
73,569\end{array}$ & $\begin{array}{c}77 \\
(174) \\
77,790\end{array}$ & $\begin{array}{l}-79 \\
(456)\end{array}$ & $\begin{array}{l}-55 \\
(150)\end{array}$ & 10,938 & \\
\hline$>0$ & $\begin{array}{l}499 \\
(412) \\
22,474\end{array}$ & $\begin{array}{c}-154 \\
(174) \\
104,506\end{array}$ & $\begin{array}{l}524 \\
(369) \\
13,027\end{array}$ & $\begin{array}{c}-290 \\
(775)\end{array}$ & $\begin{array}{c}530 \\
(414)\end{array}$ & 7,640 & $\begin{array}{c}2.1 \\
(2.0)\end{array}$ \\
\hline$\geq 0.2$ & $\begin{array}{l}815 \\
(457) \\
15,834\end{array}$ & $\begin{array}{l}-232 \\
(175) \\
95,327\end{array}$ & $\begin{array}{c}885 \\
(404) \\
9,608\end{array}$ & $\begin{array}{l}-60 \\
(600)\end{array}$ & $\begin{array}{c}874 \\
(461)\end{array}$ & 6,462 & $\begin{array}{c}3.4 \\
(1.9)\end{array}$ \\
\hline
\end{tabular}

Notes: Each cell represents a separate regression; $S_{i}$ is the share of pretax total consumer unit income from near minimum wage salaries $(<120 \%$ of the state minimum wage) earned by the top two adults in the consumer unit. See the text for details. All standard errors are cluster corrected by consumer unit.

${ }^{\mathrm{a}} S_{i}$ is defined as the share of household income coming from workers making 120 to 300 percent of the minimum wage. The sample is all households with $S_{i}=0$ in column 1.

${ }^{\mathrm{b}}$ Liquid assets are defined as savings plus checking accounts, as in Johnson, Parker, and Souleles (2006).

${ }^{\mathrm{c}} \mathrm{S}$ mall increases include years when a minimum wage increase was less than 25 cents or automated by CPI adjustments.

${ }^{\mathrm{d}}$ Marginal propensity to spend is equal to the CEX spending response reported in Table 2, column 1 divided by the income response from Table 1, column 4.

relevant social policies — such as the EITC, welfare/Temporary Assistance for Needy Families, and unemployment insurance described in online Appendix A-that could conceivably be passed in tandem with a minimum wage increase.

Using the estimated spending effect in column 1 and the income estimates from Table 1, we report the marginal propensity to spend (MPS) in column 7. We find that $S_{i} \geq 0.2$ households spend 3.4 (standard error of 1.9, where standard errors are calculated using the formulas in the online Appendix) times the short-term increase in income that arises from minimum wage hikes. There is no impact among nonminimum wage households.

To help motivate our explanation for the high MPS and to further corroborate this result, we next use the detailed spending breakdown in the CEX and the debt data from the credit bureaus to show the composition, heterogeneity, and timing of spending and debt.

Composition of Spending Responses.-Table 3 displays the estimated durables and nondurables spending responses to minimum wage increases for households where $S_{i}=0, S_{i}>0$, and $S_{i} \geq 0.2$. We find that the majority of the large spending response reported in Table 2 is from spending on durable goods. For example, households with $S_{i} \geq 0.2$ increase durables spending by $\$ 875$ (\$391) per quarter following a $\$ 1$ increase in the minimum wage, an amount that, on average, doubles the typical household's quarterly spending on durables. Again, households with no minimum wage income report no additional durables spending after the minimum wage hike. By contrast, we cannot statistically reject that the impact on nondurables 
Table 3-Decomposition of Spending Response: CEX, 1983-2008

\begin{tabular}{|c|c|c|c|c|c|c|c|c|}
\hline \multirow[b]{2}{*}{$\begin{array}{l}\text { Share of income } \\
\text { from minimum } \\
\text { wage jobs }\left(S_{i}\right)\end{array}$} & \multirow[b]{2}{*}{$\begin{array}{c}\text { Non } \\
\text { durables } \\
\text { and services } \\
(1)\end{array}$} & \multirow[b]{2}{*}{$\begin{array}{c}\text { Durables } \\
\text { (2) }\end{array}$} & \multicolumn{6}{|c|}{ Durables subcomponents } \\
\hline & & & $\begin{array}{c}\text { Furniture } \\
\text { (3) }\end{array}$ & $\begin{array}{c}\text { Floors } \\
\text { and } \\
\text { windows } \\
(4)\end{array}$ & $\begin{array}{c}\text { Misc. } \\
\text { HH } \\
\text { items } \\
(5)\end{array}$ & $\begin{array}{l}\text { Appliances } \\
\text { and } \\
\text { electronics } \\
(6)\end{array}$ & $\begin{array}{l}\text { Leisure } \\
\text { activities } \\
\text { (7) }\end{array}$ & $\begin{array}{l}\text { Trans- } \\
\text { portation } \\
\quad(8)\end{array}$ \\
\hline 0 & $\begin{array}{c}21 \\
(78)\end{array}$ & $\begin{array}{l}-78 \\
(124)\end{array}$ & $\begin{array}{c}20 \\
(18)\end{array}$ & $\begin{array}{c}1 \\
(7)\end{array}$ & $\begin{array}{c}-12 \\
(9)\end{array}$ & $\begin{array}{c}11 \\
(14)\end{array}$ & $\begin{array}{c}-2 \\
(8)\end{array}$ & $\begin{array}{l}-97 \\
(119)\end{array}$ \\
\hline$>0$ & $\begin{array}{c}116 \\
(158)\end{array}$ & $\begin{array}{c}383 \\
(369)\end{array}$ & $\begin{array}{c}9 \\
(35)\end{array}$ & $\begin{array}{c}12 \\
(10)\end{array}$ & $\begin{array}{c}47 \\
(17)\end{array}$ & $\begin{array}{c}37 \\
(46)\end{array}$ & $\begin{array}{c}-24 \\
(38)\end{array}$ & $\begin{array}{c}303 \\
(358)\end{array}$ \\
\hline$\geq 0.2$ & $\begin{array}{l}-60 \\
(188)\end{array}$ & $\begin{array}{c}875 \\
(391)\end{array}$ & $\begin{array}{c}0 \\
(35)\end{array}$ & $\begin{array}{l}10 \\
(8)\end{array}$ & $\begin{array}{c}62 \\
(18)\end{array}$ & $\begin{array}{c}35 \\
(35)\end{array}$ & $\begin{array}{c}10 \\
(15)\end{array}$ & $\begin{array}{c}759 \\
(386)\end{array}$ \\
\hline \multicolumn{9}{|c|}{ Real average amount spent $(2005 \$)$ : } \\
\hline$>0$ & 6,507 & 1,133 & 88 & 15 & 83 & 180 & 68 & 699 \\
\hline$\geq 0.2$ & 5,573 & 890 & 69 & 9 & 60 & 146 & 53 & 553 \\
\hline \multicolumn{9}{|c|}{ Conditional on purchase (2005\$): } \\
\hline $\begin{array}{l}0 \\
>0\end{array}$ & & $\begin{array}{l}1,943 \\
1,313\end{array}$ & $\begin{array}{l}607 \\
420\end{array}$ & $\begin{array}{l}340 \\
198\end{array}$ & $\begin{array}{l}248 \\
163\end{array}$ & $\begin{array}{l}357 \\
285\end{array}$ & $\begin{array}{l}172 \\
129\end{array}$ & $\begin{array}{r}11,754 \\
7,545\end{array}$ \\
\hline$\geq 0.2$ & & 1,069 & 386 & 152 & 133 & 253 & 112 & 6,713 \\
\hline
\end{tabular}

Notes: Each cell represents a separate regression. All standard errors are cluster-corrected by consumer unit.

and services is different from 0 . The results are particularly striking considering that nondurables and services comprise 85 percent of total spending.

Since most of the spending response is in durables, the rest of the table decomposes this category more finely. In particular, we classify durable goods into six categories: furniture, floors and windows, appliances and electronics, leisure activities, miscellaneous household items, and net outlays on transportation (measured as the difference between the price of the vehicle purchased and the vehicle sold). ${ }^{18}$

For most categories, the impact is small and hard to distinguish from zero. The notable exception is transportation goods. Households with $S_{i} \geq 0.2$ spend an additional $\$ 759$ (\$386) on transportation durables, representing over 90 percent of the total spending response.

Not surprisingly, a small number of households are responsible for this durables spending. For households with $S_{i} \geq 0.2$, a fixed effects linear probability model shows that new vehicle purchases rise 2.7 percent ( 1 percent) per quarter (column 1 of table 4). Column 3 of Table 4 shows that those additional purchases lead to an extra \$511 (\$212) in quarterly expenditures, on average. There is little impact on used vehicles (columns 2 and 4) or other transportation items (not shown), possibly because they might be harder to debt-finance. Once again, $S_{i}=0$ households show no additional spending on vehicles.

\footnotetext{
${ }^{18}$ Floors and windows include carpets, rugs, curtains, drapes, and blinds. Appliances and electronics include kitchen and laundry appliances, televisions, VCRs, DVDs, stereo and sound equipment, computers, telephones, PDAs, antennas, and satellite dishes. Leisure activities include musical instruments, sports equipment, bikes, camping equipment, toys, games, playground equipment, arts and crafts, CDs, and DVDs. Miscellaneous household items include clocks, lamps, linens, silverware, plates, glasses, decorative items, outdoor equipment, small appliances, smoke alarms, cleaning equipment, tools, lawn equipment, window air conditioners, and portable heaters and coolers. Transportation includes cars, trucks, vans, motorcycles, and boats. These purchases are net of trade-ins.
} 
Table 4-Decomposition of Transportation Spending Response: CEX, 1983-2008

\begin{tabular}{|c|c|c|c|c|c|c|c|c|}
\hline \multirow[b]{3}{*}{$\begin{array}{l}\text { Share of income } \\
\text { from minimum } \\
\text { wage jobs }\left(S_{i}\right)\end{array}$} & \multirow{2}{*}{\multicolumn{2}{|c|}{$\begin{array}{l}\text { Probability of purchase } \\
\qquad(1983-2008)\end{array}$}} & \multirow{2}{*}{\multicolumn{2}{|c|}{$\begin{array}{l}\text { Expenditure } \\
(1983-2008)\end{array}$}} & \multicolumn{4}{|c|}{ Expenditures on new cars and trucks (1992-2008) } \\
\hline & & & & & \multirow[b]{2}{*}{$\begin{array}{l}\text { Expenditure } \\
\quad(5)\end{array}$} & \multirow[b]{2}{*}{$\begin{array}{c}\text { Net } \\
\text { outlay, } \\
\text { not } \\
\text { financed } \\
(6)\end{array}$} & \multicolumn{2}{|c|}{ Financed with loan } \\
\hline & $\begin{array}{c}\text { New } \\
\text { cars/ } \\
\text { trucks } \\
(1)\end{array}$ & $\begin{array}{c}\text { Used } \\
\text { cars/ } \\
\text { trucks } \\
(2)\end{array}$ & $\begin{array}{c}\text { New } \\
\text { cars/ } \\
\text { trucks } \\
(3)\end{array}$ & $\begin{array}{c}\text { Used } \\
\text { cars/ } \\
\text { trucks } \\
(4)\end{array}$ & & & $\begin{array}{c}\text { Down } \\
\text { payment } \\
(7)\end{array}$ & $\begin{array}{c}\text { Expenditure } \\
\text { less } \\
\text { down } \\
\text { payment } \\
(8)\end{array}$ \\
\hline 0 & $\begin{array}{l}-0.003 \\
(0.004)\end{array}$ & $\begin{array}{c}0.006 \\
(0.005)\end{array}$ & $\begin{array}{c}-37 \\
(92)\end{array}$ & $\begin{array}{c}1 \\
(65)\end{array}$ & $\begin{array}{l}-115 \\
(120)\end{array}$ & $\begin{array}{c}-52 \\
(63)\end{array}$ & $\begin{array}{c}-15 \\
(18)\end{array}$ & $\begin{array}{c}-48 \\
(92)\end{array}$ \\
\hline$>0$ & $\begin{array}{c}0.024 \\
(0.009)\end{array}$ & $\begin{array}{c}-0.005 \\
(0.021)\end{array}$ & $\begin{array}{c}440 \\
(182)\end{array}$ & $\begin{array}{l}-107 \\
(196)\end{array}$ & $\begin{array}{c}378 \\
(196)\end{array}$ & $\begin{array}{c}80 \\
(62)\end{array}$ & $\begin{array}{l}115 \\
(63)\end{array}$ & $\begin{array}{c}183 \\
(145)\end{array}$ \\
\hline$\geq 0.2$ & $\begin{array}{c}0.027 \\
(0.010)\end{array}$ & $\begin{array}{c}0.004 \\
(0.026)\end{array}$ & $\begin{array}{c}511 \\
(212)\end{array}$ & $\begin{array}{c}19 \\
(204)\end{array}$ & $\begin{array}{c}431 \\
(233)\end{array}$ & $\begin{array}{c}45 \\
(71)\end{array}$ & $\begin{array}{l}121 \\
(75)\end{array}$ & $\begin{array}{c}265 \\
(174)\end{array}$ \\
\hline \multicolumn{9}{|c|}{ Average ( $2005 \$$ for expenditures $)$ : } \\
\hline 0 & 0.027 & 0.058 & 556 & 458 & 554 & 80 & 58 & 416 \\
\hline$>0$ & 0.013 & 0.075 & 228 & 423 & 213 & 12 & 24 & 177 \\
\hline$\geq 0.2$ & 0.009 & 0.069 & 153 & 367 & 134 & 6 & 16 & 111 \\
\hline \multicolumn{9}{|c|}{ Conditional on positive number: } \\
\hline 0 & & & 20,643 & 7,938 & 22,477 & 22,468 & 4,345 & 19,764 \\
\hline$>0$ & & & 18,021 & 5,672 & 19,956 & 15,456 & 3,680 & 17,859 \\
\hline$\geq 0.2$ & & & 16,996 & 5,284 & 18,423 & 15,392 & 3,378 & 16,269 \\
\hline
\end{tabular}

Notes: Probability of a purchase is estimated using a linear probability model with individual fixed effects. Each cell represents a separate regression. All standard errors are cluster-corrected by consumer unit.

Column 5 presents estimates of the spending response over the 1992 to 2008 period, where additional questions were asked about the financing of new vehicle purchases. Column 6 shows that only $\$ 45$ of the $\$ 431$ spending response comes from vehicle purchases that were not financed. Of the remaining $\$ 386, \$ 121$ is an increase in down payments (column 7) and the remainder comes from loans collateralized by the vehicle (column 8). Thus, most of the additional spending on new vehicles is debt-financed.

Distribution of the Spending Responses.-Since an additional 2.7 percent of minimum wage households purchase a new vehicle in the quarters immediately following a minimum wage increase, we would expect that the spending response is concentrated among a minority of households. This pattern is displayed in Figure 1, which graphs a set of quantile regressions of total spending, ranging from the 10th to 98th percentiles (quantiles shown on the $x$-axis), for households where either $S_{i}=0$ (connected by the dashed line) or $S_{i} \geq 0.2$ (solid line). ${ }^{19}$ The key insight is that, for minimum wage households, the mean response is much bigger than the median response, the latter of which is not statistically or economically different from zero. In particular, the average effect reported in earlier tables appears to be substantially driven by households beyond the 90th percentile of the distribution. We would not want to overemphasize these results given their precision. Indeed,

\footnotetext{
${ }^{19}$ In order to remove the household fixed effect, we first demeaned all variables, and then used standard quantile estimation techniques. Because a quantile estimator is not a linear model, demeaning the data will generate inconsistent estimates. When we performed our procedure on our simulated data, however, we found that this problem is very minor. Since we perform identical procedures on the simulated data, the estimates on actual and simulated data are comparable.
} 


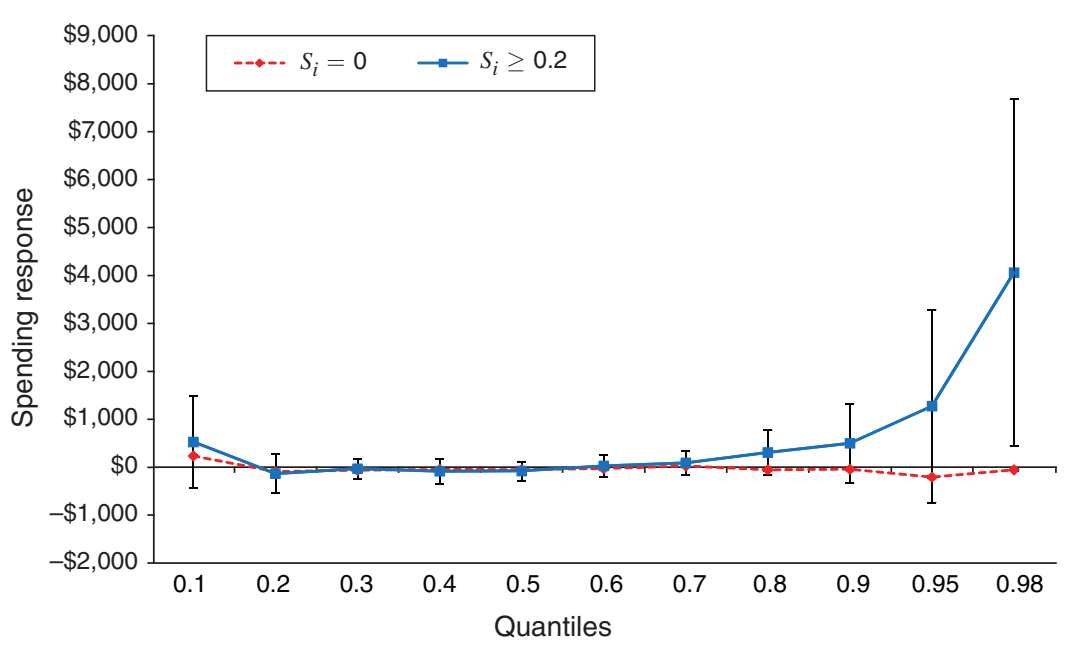

Figure 1. Spending Response to Change in Minimum Wage, CEX Quantile Regressions

90 percent error bands show that the estimates are not statistically distinguishable from zero. But the point estimates are broadly consistent with the heterogeneity in spending responses that we would expect given that average spending is driven by expensive durables purchases.

Timing of Spending.-Figure 2 panels A-D show the timing of the spending response for the $S \geq 0.2$ households. The plots are based on equation (1) where we allow for three quarters of lags and leads of the minimum wage $(K=3)$. The figures highlight three additional key facts.

First, the initial total spending increase (thick line in Figure 2, panel A) happens primarily in the quarter of the minimum wage change. There is little evidence that total spending increases prior to the minimum wage change, even though minimum wage hikes are typically passed into law 6 to 18 months prior to the time of the hike. 20

Second, while total spending is flat prior to the minimum wage increase, this masks an offsetting increase in nondurables and services (dashed line, Figure 2, panel A) and a decline in durables spending (dotted line, Figure 2, panel A). When the hike occurs (defined as $t=0$ ), durables spending spikes up. Though nondurables and service spending increases two quarters before the hike, it does not increase further during the quarter of the hike.

Third, spending does not immediately revert back to prehike levels after the initial increase. Rather, it bounces around $\$ 1,000$ per quarter in the near term before starting to slowly decline.

For clarity, standard errors are presented in the other panels of Figure 2. Generally, we find that the patterns in nondurables spending (Figure 2, panel C) are not

\footnotetext{
${ }^{20}$ For example, of the 19 state minimum wage changes between 2000 and 2004 (excluding CPI adjustments), the median time between legislation and enactment date was 9 months. Only two increases (California in 2001 and Rhode Island in 2000) occurred less than five months after the bill's passage. Even among those exceptions, a public legislative debate began well before passage.
} 
Panel A. Decomposition of CEX spending response to a change in the minimum wage

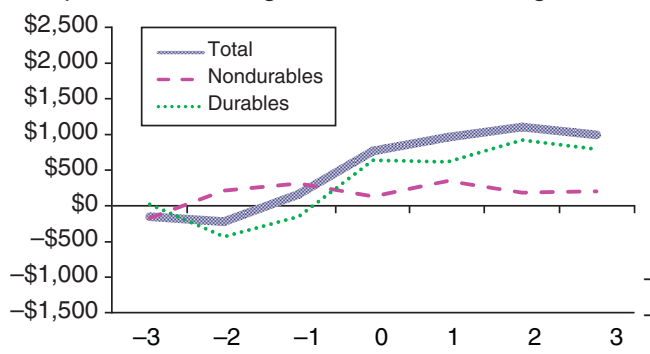

Quarters around minimum wage increase at $t=0$

Panel C. Nondurables response to a minimum wage change

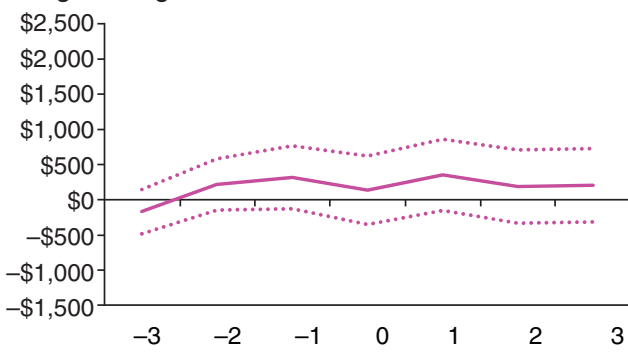

Quarters around minimum wage increase at $t=0$
Panel B. Total spending response to a change in the minimum wage

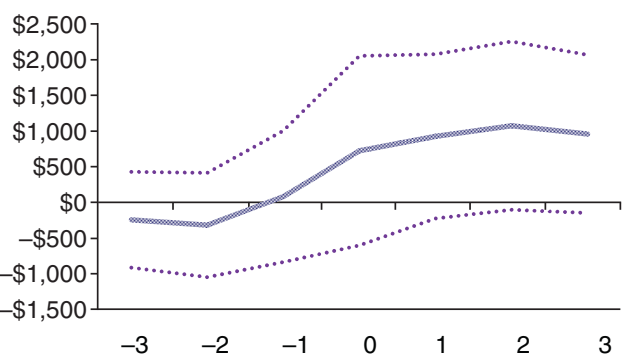

Quarters around minimum wage increase at $t=0$

Panel D. Durables response to a minimum wage change

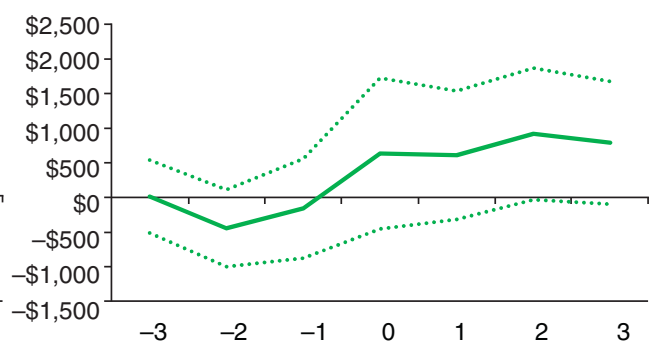

FIGURE 2

Notes: Dashed lines are 90 percent confidence intervals. Sample is $S_{i} \geq 0.2$. Plots are very similar for $S_{i}>0$.

statistically different from zero, which is unsurprising given the nondurables results in Table 3. In contrast, durables spending (Figure 2, panel D) tends to be statistically and economically significant and, as we argue later, broadly consistent with the borrowing constraint model we introduce in Section III.

\section{Debt}

If spending rises more than income after a minimum wage increase, it follows that net financial assets decline. Although we do not have panel data on assets, we have panel data on debt. Table 5 shows quarterly changes in debt, as measured by the credit bureaus, after a minimum wage hike, broken into subcategories: vehicle loans, home equity loans, mortgages, and credit card debt. The results are reported separately for individuals reporting annual income above and below $\$ 20,000$ at the time of credit card application. ${ }^{21}$

In each category, debt increases after a minimum wage increase, but particularly in collateralized loans tied to vehicles. We estimate that a $\$ 1$ minimum wage

\footnotetext{
${ }^{21}$ Recall, we do not have wages for this sample and therefore cannot compute $S_{i}$. All observations are weighted based on the estimated relationship, described in Section IIA, between annual earnings and an indicator for whether the hourly wage is at or below 120 percent of the minimum wage.
} 
Table 5-Debt Response to Change in the Minimum Wage Credit Bureau and Credit Card Data, 1995-2008

\begin{tabular}{lcccccc}
\hline \hline $\begin{array}{l}\text { Income at credit } \\
\text { card application }\end{array}$ & $\begin{array}{c}\text { Auto } \\
\text { debt } \\
(1)\end{array}$ & $\begin{array}{c}\text { Home equity } \\
\text { debt } \\
(2)\end{array}$ & $\begin{array}{c}\text { Mortgage } \\
\text { debt } \\
(3)\end{array}$ & $\begin{array}{c}\text { Credit card } \\
\text { debt } \\
(4)\end{array}$ & $\begin{array}{c}\text { Total } \\
\text { debt } \\
(5)\end{array}$ & $\begin{array}{c}\text { Total minus } \\
\text { mortgage debt } \\
(6)\end{array}$ \\
\hline$\geq 20,000$ & 17 & 10 & 7 & 12 & 47 & 38 \\
& $(99)$ & $(85)$ & $(136)$ & $(7)$ & $(134)$ & $(75)$ \\
$<20,000$ & 205 & 130 & 155 & 106 & 603 & 440 \\
& $(86)$ & $(86)$ & $(371)$ & $(96)$ & $(338)$ & $(148)$ \\
\hline
\end{tabular}

Notes: Data on collateralized debt (auto, home equity, and mortgage) are from the credit bureaus. Data on credit card debt is based on cards from our institution. All observations are weighted by $P_{i}$, the probability that an individual account holder is a minimum wage worker. See text for details. Sample sizes are 4 million and 582,000 for account holders with incomes of at least $\$ 20,000$ and incomes less than $\$ 20,000$, respectively. Each cell represents a separate regression. All standard errors are cluster-corrected by account holder.

increase causes auto loan balances to increase by \$205 (\$86) per quarter, similar to the increase in debt collateralized by vehicles estimated from the CEX and shown in column 10 of Table $4 .{ }^{22}$ Furthermore, home equity lines, which can be used to purchase vehicles, ${ }^{23}$ rise by $\$ 130(\$ 86)$, Auto loans, home equity, and credit card debt combined increase by $\$ 440(\$ 148) .{ }^{24}$ There is no increase in debt among higher income $(\geq \$ 20,000)$ individuals.

These numbers are consistent with the income and spending results presented thus far. Assuming that financial assets do not change after a minimum wage hike, rearranging a standard asset accumulation equation (like equation 5 below) shows that spending is equal to the sum of the debt and income responses. Taking the mean income response of $S_{i}>0$ and $S_{i} \geq 0.2$ minimum wage households to be $\$ 241$ and $\$ 238$ and the debt response to be $\$ 440$ (this cannot be estimated by specific levels of $S_{i}$ ), we impute a spending response of $\$ 682$ and $\$ 677$, close to what we observe in the CEX, with standard errors of $\$ 168$ and $\$ 168$. This result is shown in Table 6 , column 2. A weighted average of the imputed and estimated spending effects is $\$ 655(\$ 155)$ and $\$ 694(\$ 158)$ for $S_{i}>0$ and $S_{i} \geq 0.2$ households. Such a spending response implies a marginal propensity to spend of roughly three with a $t$-statistic of just over three. 25

Figure 3 displays the dynamics of household debt (auto, home equity, and credit card) in the nine quarters that follow a minimum wage increase. To provide a longer panel, this figure is based on the sole cohort of accounts that are followed for four years starting in January 2000 rather than the series of two-year panels used in Table 5. The figure clearly shows total debt rising in the first year after a minimum

\footnotetext{
${ }^{22}$ Likewise, we find that new loans increase by 2.8 percent (with a standard error of 0.8 percent) in the first quarter after a minimum wage increase. Roughly three-quarters are automobile loans and the remainder are home equity loans. Again, these figures are comparable to the estimated increase in automobile purchases in the CEX (column 1 of Table 4 ).

${ }^{23}$ According to CNW Research, home equity lines were used in 12 to 14 percent of vehicle purchases made between 2003 and 2007. These data were generously provided to us by CNW. They are based on monthly phone and mail interviews of more than 14,000 households.

${ }^{24}$ The estimated credit card debt response of \$105 (\$95) is based only on our institution. If we use accounts where the balance ratio is high, however, and therefore the individual relies primarily on only our card, the change in debt following a minimum wage increase is similar, albeit less precisely estimated. Our total debt also excludes loans not recorded by the credit bureau, including educational debt.

${ }^{25}$ Standard error derivations are shown in online Appendix B.
} 
Table 6-Alternative Estimates of Spending Response

\begin{tabular}{|c|c|c|c|c|}
\hline \multirow[b]{2}{*}{$\begin{array}{l}\text { Share of income } \\
\text { from minimum } \\
\text { wage jobs }\left(S_{i}\right)\end{array}$} & \multicolumn{3}{|c|}{ Spending } & \multirow[b]{2}{*}{$\begin{array}{l}\text { Weighted average } \\
\text { marginal propensity } \\
\text { to spend }{ }^{\mathrm{c}} \\
\text { (4) }\end{array}$} \\
\hline & $\begin{array}{c}\mathrm{CEX}^{\mathrm{a}} \\
\text { (1) }\end{array}$ & $\begin{array}{c}\text { Imputed } \\
\text { from } \\
{\text { income } / \mathrm{debt}^{\mathrm{b}}}^{\text {(2) }}\end{array}$ & $\begin{array}{l}\text { Weighted } \\
\text { average } \\
(3)\end{array}$ & \\
\hline$>0$ & $\begin{array}{c}499 \\
(412)\end{array}$ & $\begin{array}{c}682 \\
(168)\end{array}$ & $\begin{array}{c}655 \\
(156)\end{array}$ & $\begin{array}{c}2.8 \\
(0.9)\end{array}$ \\
\hline$\geq 0.2$ & $\begin{array}{c}815 \\
(457)\end{array}$ & $\begin{array}{c}677 \\
(168)\end{array}$ & $\begin{array}{c}694 \\
(158)\end{array}$ & $\begin{array}{c}2.9 \\
(0.9)\end{array}$ \\
\hline
\end{tabular}

${ }^{\mathrm{a}}$ From Table 2, column 1.

${ }^{\mathrm{b}}$ Table 1, column 4 plus Table 5, column 6. See text.

${ }^{\mathrm{c}}$ Column 3 of this table divided by column 4 of Table 1. See online Appendix B for details on the standard error calculations.

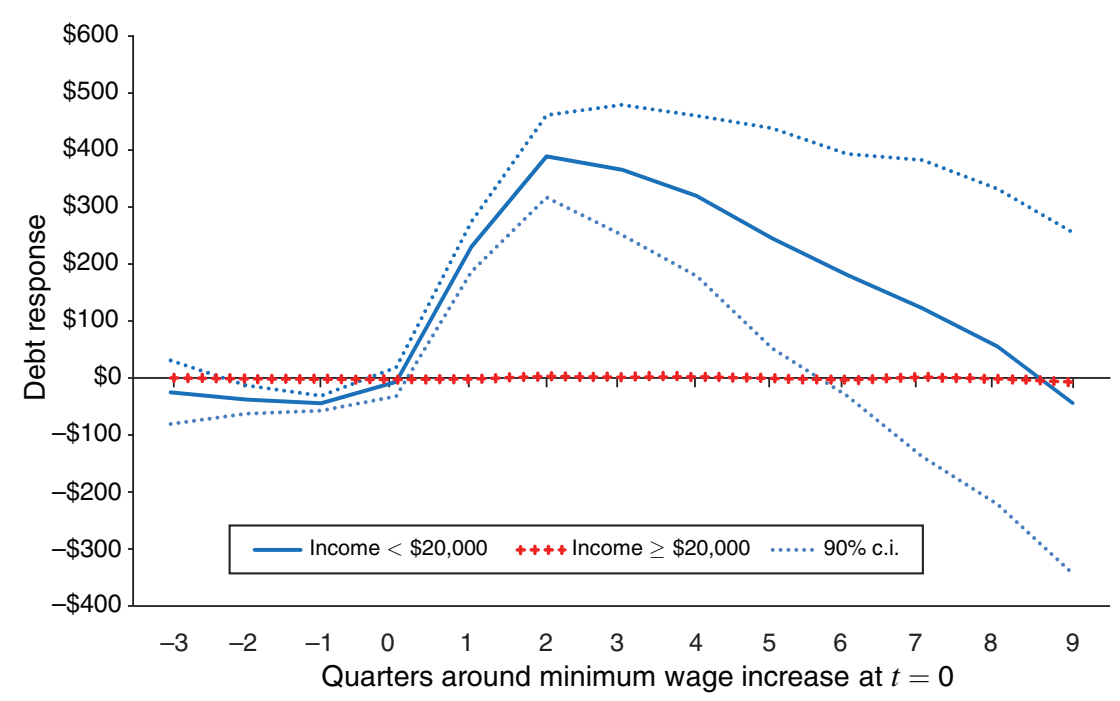

Figure 3. Debt (Auto, Home Equity, and Credit Card) Response to a Change in the Minimum Wage Credit Card/Credit Bureau Data

wage increase for households with income below $\$ 20,000$ (solid line) but not for higher income households (crossed line). In subsequent quarters, debt rises by less, to the point that by the end of the second year, we cannot reject that debt among lowincome households is beginning to fall. This pattern provides direct evidence that much of the early consumption response is in fact debt-financed, and corroborates the independent CEX measures of debt-financed vehicle spending and the large MPS estimates arising from the income and spending regressions.

Finally, Figure 4 plots a set of quantile debt regressions, ranging from 0.10 to 0.98 , for households with $<\$ 20,000$ and $\geq \$ 20,000$ in income. We again find that the median and mean effects are quite different. The average effect reported in Table 5 is driven by the upper tails of the debt response distribution, consistent with the heterogeneity in spending responses that we would expect given that spending is driven by expensive durables purchases. 


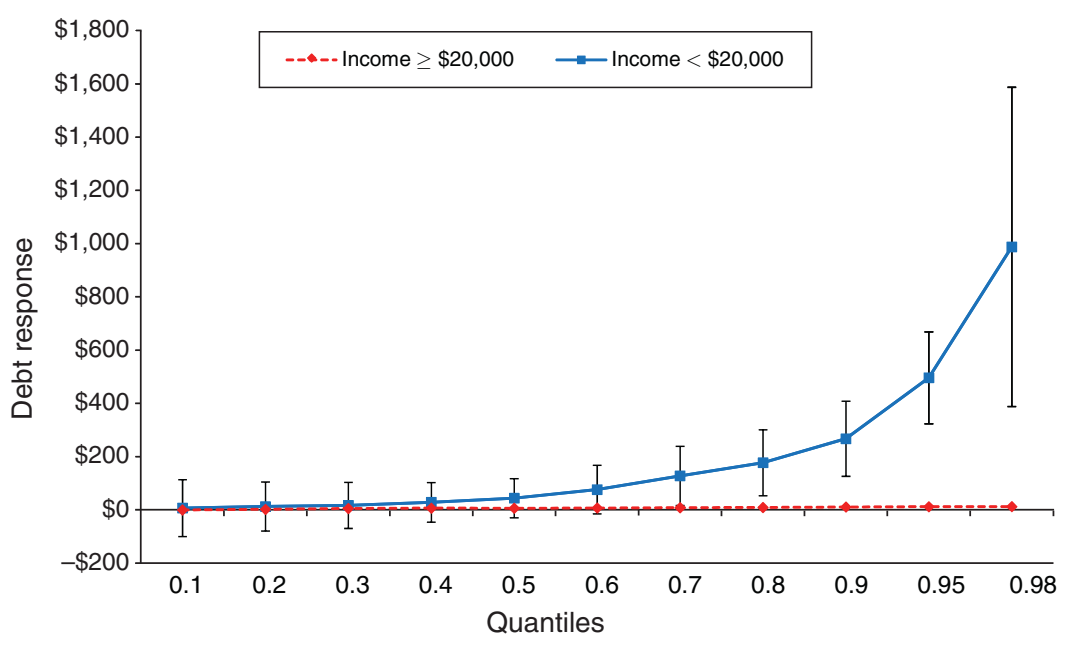

Figure 4. Debt Response to Change in Minimum Wage Credit Bureau QuANTILE REgRESSIONS

Despite the rise in debt, we find little evidence of an increase in defaults in the near term. The probability that an account is 60 days past due actually falls slightly from 5.6 to 5.45 percent (with a standard error of 0.14 percent) six months after a minimum wage increase. This result is again based on a single cohort of credit bureau accounts, but the cohort is large and followed for four years, and the linear probability models include controls for account holder fixed effects and time dummies.

\section{E. Summary of Empirical Results}

We identify several stylized facts about income, spending, and debt following a minimum wage increase.

First, spending and income increase approximately $\$ 700$ and $\$ 250$ per quarter immediately following a minimum wage hike among households that derive income from minimum wage jobs. Consequently, we should see debt rising dramatically, a pattern that we document with the CEX and credit bureau data.

Second, the majority of the spending response occurs in the form of durable goods and, in particular, new vehicles that are debt-financed. Consequently, the spending response is concentrated among a small number of households.

Third, total spending begins to rise within one quarter of a minimum wage increase rather than at the legislation's passage, which typically occurs 6 to 18 months prior. Moreover, there are some compositional differences in the timing. Prior to the minimum wage hike, durables spending falls and nondurables spending rises by roughly equal amounts, so the total spending response is almost zero. After the minimum wage hike, nondurables spending barely increases further, but durables spending immediately spikes upward.

Finally, high levels of durables spending and debt accumulation persist for several quarters after a minimum wage hike. 


\section{A Model with Durable Goods and Borrowing Limits}

In this section, we describe a model that can explain many of these key empirical findings. Define $C_{t}$ as consumption of nondurable goods at time $t$ and $D_{t}$ as the durables stock at time $t$ (where time is measured in quarters). The household maximizes

$$
E_{t_{0}} \sum_{t=t_{0}}^{T} \beta^{t}\left(C_{t}^{1-\theta} D_{t}^{\theta}\right)^{1-\gamma} /(1-\gamma)
$$

subject to the constraints below. Within-period preferences are Cobb-Douglas between durables and nondurables. Thus, consistent with the evidence, expenditure shares are assumed constant. ${ }^{26}$ We model individuals for 188 quarters, from age 18 to 65 .

The asset accumulation equation is

$$
A_{t+1}=(1+r) A_{t}+Y_{t}-C_{t}-I_{t}, \quad A_{T+1} \geq 0,
$$

where $A_{t}$ denotes net financial assets (i.e., financial assets less debt), $r$ the interest rate, $I_{t}$ investment in consumer durables, and $Y_{t}$ income. The law of motion for durables is

$$
D_{t+1}=(1-\delta) D_{t}+I_{t}
$$

where $\delta$ is the depreciation rate.

In contrast to much of the literature, but often observed in practice, we allow individuals to borrow against durable goods. Assets must satisfy the borrowing constraint

$$
-A_{t} \leq(1-\pi) D_{t}
$$

where $\pi$ is the down payment rate, or the fraction of the value of newly purchased durable goods that does not serve as collateral. Such a constraint may exist because of limited enforcement, where collateral guards against the temptation to default (e.g., Kiyotaki and Moore 1997). Rewriting equation (7) shows that "voluntary equity," defined as

$$
\text { voluntary equity } \text { }_{t} \equiv A_{t}+(1-\pi) D_{t} \text {, }
$$

must always be greater than 0 .

Finally, the income process is

$$
\ln Y_{t}=\alpha_{t}+P_{t}+u_{t}
$$

\footnotetext{
${ }^{26}$ For example, durables share of expenditures is 17 and 15 percent for CEX households with and without adult minimum wage earners, respectively. Fernandez-Villaverde and Krueger (2011) review the evidence on the substitutability of durables and nondurables and conclude that Cobb-Douglas is consistent with the evidence.
} 
where $\alpha_{t}$ is the life-cycle profile of income. We assume that $\alpha_{t}=\alpha_{t_{0}}+\alpha_{1} t$ for the first 80 quarters of an individual's life, and is constant at $\alpha_{t}=\alpha_{t_{0}}+\alpha_{1} \times 80$ afterward, which is consistent with estimates showing that income growth tapers off after 20 years in the labor force (e.g., Gourinchas and Parker 2002) for low-skill workers. Because we found virtually no change in employment or hours worked following minimum wage hikes, we do not allow for an hours choice.

The stochastic components of income are the white noise term $u_{t}$ and the $\operatorname{AR}(1)$ term $P_{t}$

$$
P_{t+1}=\rho P_{t}+\epsilon_{t+1},
$$

where $\epsilon_{t} \sim N\left(0, \sigma_{\epsilon}^{2}\right)$ and $u_{t} \sim N\left(0, \sigma_{u}^{2}\right)$.

The model is complex and thus we solve it numerically using the solution techniques described in the online Appendix.

\section{A. Calibration of the Model}

To calibrate the model, parameters are set to the values listed in Table 7. In this section, we highlight those that are less standard.

First, we pick $\theta$ to match the CEX's estimate of nonresidential durables' share of total nonresidential expenditure, $I_{t} /\left(I_{t}+C_{t}\right)$. Second, for $\delta$, we use the Campbell and Hercowitz (2003) estimate of quarterly depreciation rates for nonresidential durable goods, which is similar to Adda and Cooper (2000). Third, we choose $1+r=\sqrt[4]{1.03}$ to correspond to a 3 percent real annual rate of interest, a standard in the literature.

Fourth, we assume the down payment rate, $\pi$, is 0.4. The Federal Reserve's G19 Consumer Credit release reports that the loan-to-value ratio, $(1-\pi)$, on new cars averaged 90 percent between 1982 and 2005, covering most of the years in our CEX sample. Only 58 percent of our estimated durables spending response came from new vehicles, however. ${ }^{27}$ The rest of durables spending likely requires larger down payments, including some products for which collateralized financing may not be readily available (e.g., small appliances).

Fifth, we choose $\beta$ to match the share of households that are liquidity-constrained. Using data from the 1989 to 2007 waves of the Survey of Consumer Finances (SCF), the 25 th and 50th percentiles of voluntary equity $\left(A_{t}+(1-\pi) D_{t}\right)$ at ages 22,34 , and 50 (which are the midpoints of the age tertiles of CEX minimum wage workers) are $-\$ 70$ and $\$ 452 .{ }^{28}$ We choose $\beta=\sqrt[4]{0.93}$, or 0.93 at an annual rate. This value of $\beta$ minimizes the sum of squared deviations between model-predicted and empirical values of voluntary equity at the 25 th and 50 th percentiles.

\footnotetext{
${ }^{27}$ For example, Tables 3 and 4 show that for $S_{i} \geq 0.2$, the durables response is $\$ 875$ and the new vehicle response is $\$ 511$.

${ }^{28}$ The 75 th percentile of voluntary equity is $\$ 7,563$, and thus the 75 th percentile of individuals do not appear liquidity constrained. The statistics above were calculated for ages 21,33 , and 49 , which is one year before the age of the minimum wage hike. We do the calculation one year before the hike so that the model predictions are unaffected by savings behavior in response to the minimum wage hike. The 25th, 50th, and 75th percentiles of "voluntary equity" for the full SCF at all ages are $\$ 204, \$ 3,118$, and $\$ 12,034$, which shows that the distribution is somewhat sensitive to the sample used.
} 
Table 7-Parameters Used for Calibration

\begin{tabular}{lll}
\hline \hline Parameter & Quarterly value & \multicolumn{1}{c}{ Definition } \\
\hline$\beta$ & $\sqrt[4]{0.93}$ & Discount factor \\
$\gamma$ & 2 & Coefficient of relative risk aversion \\
$\theta$ & 0.15 & Utility weight on durables \\
$T-t_{0}$ & 188 & Number of time periods \\
$r$ & $\sqrt[4]{1.03}-1$ & Quarterly interest rate \\
$\delta$ & 0.034 & Durables depreciation rate \\
$\pi$ & 0.4 & Down payment rate \\
$E(Y)$ & $\$ 4,500$ & Average income of minimum wage households \\
$\alpha_{1}$ & 0.0108 & Income growth \\
$\rho$ & 0.995 & Autocorrelation of income \\
$\sigma_{\epsilon}^{2}$ & 0.005 & Variance of AR(1) innovations \\
$\sigma_{u}^{2}$ & 0.05 & Variance of transitory innovations \\
\hline
\end{tabular}

Lastly, we estimate the parameters of the income process using the SIPP. We estimate $\alpha_{1}=0.0108$ using a household fixed effects regression of log income on age for households with minimum wage workers and heads younger than $40 .{ }^{29} \mathrm{We}$ choose $\alpha_{t_{0}}$ such that average income across ages 22, 34, and 50, is $\$ 4,500$, roughly the average of all minimum wage households in the SIPP, CEX, and SCF samples. ${ }^{30}$ We assume $\rho=0.995$ (or 0.98 at an annual rate), $\sigma_{u}^{2}=0.05$, and $\sigma_{\epsilon}^{2}=0.005$, similar to Gourinchas and Parker (2002), Meghir and Pistaferri (2004), and Kaplan and Violante (2010).

\section{B. Initial Joint Distribution of the State Variables}

Each simulated individual begins her life with a vector of state variables: the permanent component of income, net financial assets, ${ }^{31}$ and the stock of durable goods. We generate the state vector by taking random draws of minimum wage households headed by an individual aged 18 to 25 in the SCF. Online Appendix Table A4 present key descriptive statistics.

\section{Modeling Minimum Wage Hikes}

In order to assess the impact of the minimum wage on spending, we simulate the model with and without a minimum wage hike. The hike is modeled as an innovation to the deterministic component of income, $\alpha_{t}$. Given our estimates in Section IIB, we assume that income increases by $\$ 250$ immediately following the hike. We assume that the size of income gain does not vary with age. That initial gain is assumed to

\footnotetext{
${ }^{29}$ This translates into 4 percent average annual income growth, close to estimates for early career low-skill workers (e.g., French, Mazumder, and Taber 2006).

${ }^{30}$ For example, SCF mean income of minimum wage workers is $\$ 4,748$ at all ages, and $\$ 4,252$ when averaging over ages 21,33 , and 49 .

${ }^{31}$ More precisely, the state variable is cash-on-hand, which is the sum of net financial assets and current income.
} 


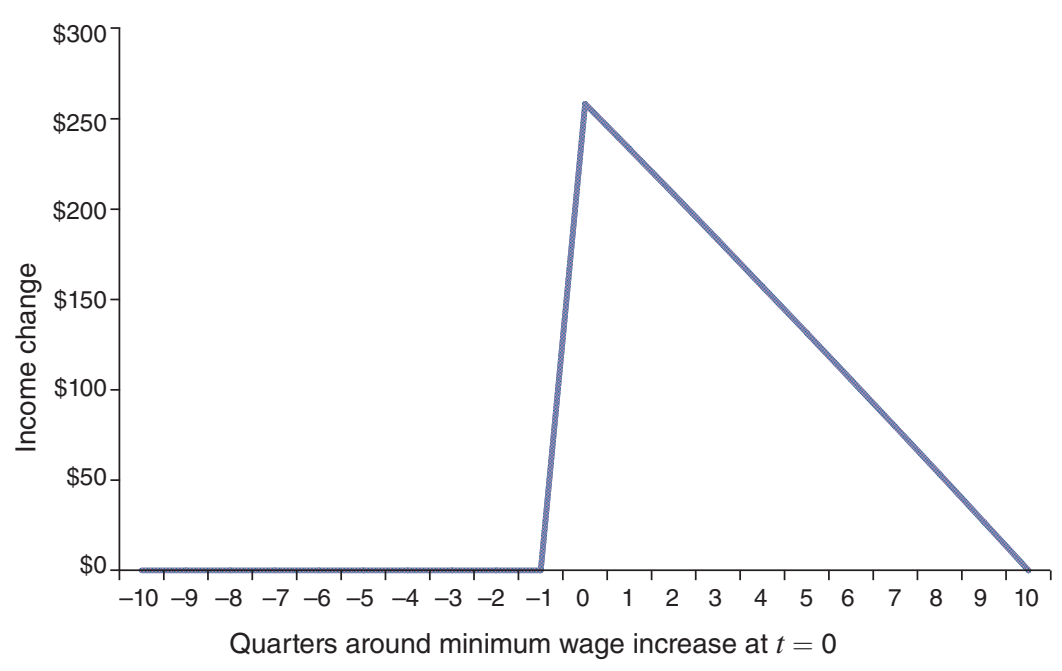

Figure 5. Simulated Income Change ARound a Minimum Wage Increase

dissipate over the next 10 quarters. ${ }^{32}$ After 10 quarters, income once again grows by 1.08 percent per quarter for younger households and 0 percent for older households.

We simulate the model, with and without the minimum wage-induced income gain, at ages 22, 34, and 50. Figure 5 plots the difference in income profiles between simulated individuals who received a minimum wage hike and those who did not, averaged over the ages surrounding the three minimum wage hikes. In total, a 10 percent minimum wage hike increases total discounted lifetime income by just over $\$ 1,250$.

Finally, we assume that households learn about the minimum wage hike three quarters before it occurs. This is consistent with the observation that minimum wage legislation is typically passed into law at least three quarters before the minimum wage hike is implemented.

\section{Model Results without Uncertainty and Borrowing Constraints}

We first describe the calibration results for the case when households face neither borrowing constraints (so $\pi$ is unimportant) nor income uncertainty $\left(\sigma_{u}^{2}=\sigma_{\epsilon}^{2}=0\right.$ ) in order to clarify the dimensions on which this model succeeds in describing the empirical facts. We use the parameters in Table $7,{ }^{33}$ with the exception that the time discount factor $\beta$ is set to 1.01 to allow the model to generate a more plausible asset

\footnotetext{
${ }^{32}$ At age 22 this means that rather than grow at 1.08 percent per quarter, income only grows by 0.3 percent in the nine quarters after the hike for households receiving a minimum wage increase. This allows any income gain from the minimum wage to be eroded after 10 quarters.

${ }^{33}$ We continue to make the model predicted mean income $E\left(Y_{t}\right)=\$ 4,500$ and income jump after a minimum wage hike be $\$ 250$. Because $E\left(Y_{t}\right)=\exp \left(\alpha_{t_{0}}+\left(\sigma_{P_{t}}^{2}+\sigma_{u}^{2}\right) / 2\right.$ ) (where $\sigma_{P_{t}}^{2}$ is the variance of the permanent component of income) and earnings variance varies across specifications, we adjust $\alpha_{t_{0}}$ and how $\alpha_{t}$ changes after minimum wage hikes across specifications to hold $E\left(Y_{t}\right)=\$ 4,500$ and the size of the income jump constant across specifications.
} 


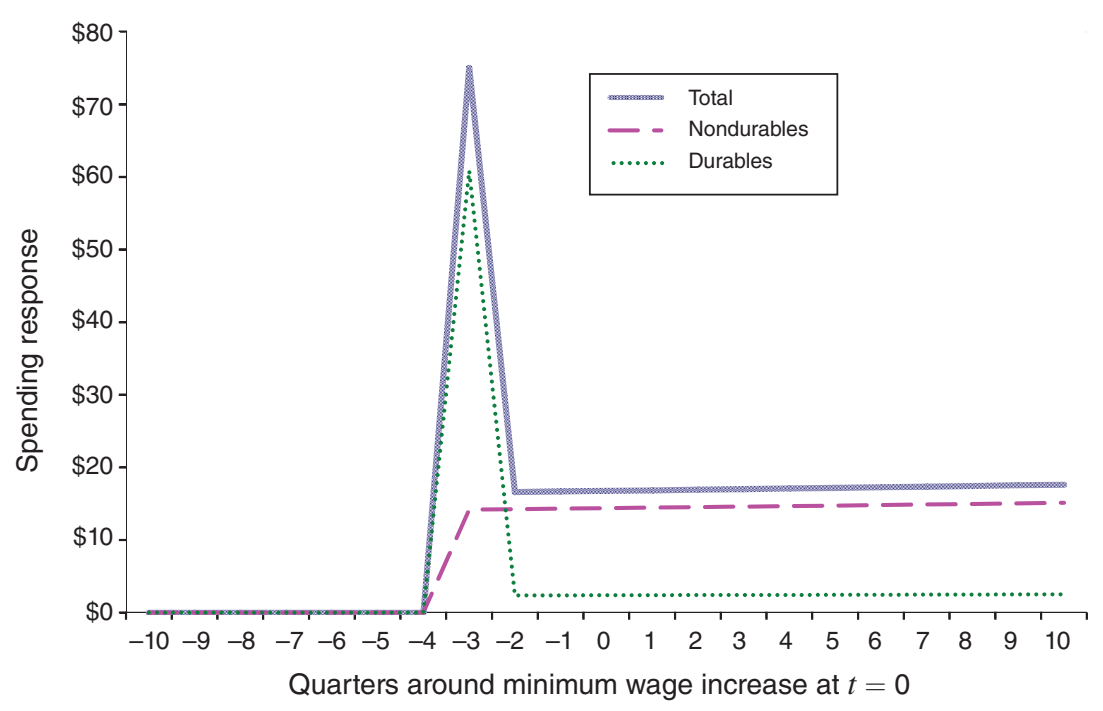

Figure 6. Spending Change around a Minimum Wage Increase Simulation without Borrowing Constraints

distribution. When $\beta=\sqrt[4]{0.93}$, median net financial assets at the time of the minimum wage hike are implausibly low. ${ }^{34}$

Figure 6 shows the predicted spending response to a minimum wage hike (averaged over ages 22, 34, and 50); i.e., the difference between predicted spending of those who received a minimum wage hike and those who did not. Three key features of the figure are worth highlighting.

First, the initial spending increase is $\$ 75$, followed by $\$ 17$ spending per quarter thereafter. The present value of this stream of spending is roughly $\$ 1,250$, the lifetime income gain from the minimum wage hike. These estimates are substantially smaller in the near term than what we observe in the spending data. To better understand the size of the spending responses, we use the parameter values in Table 7 and formulas in the online Appendix to show that if $T$ is large or there is a resale market for durables, the marginal propensity to spend on nondurables and durables is well below 1:

$$
\left.\frac{\partial C_{0}}{\partial A_{0}}\right|_{D_{0}}=(1-\theta)\left[\frac{1-\frac{(\beta(1+r))^{\frac{1}{\gamma}}}{1+r}}{1-\left(\frac{(\beta(1+r))^{\frac{1}{\gamma}}}{1+r}\right)^{T+1}}\right]=0.01,
$$

$$
\left.\frac{\partial \boldsymbol{I}_{0}}{\partial A_{0}}\right|_{D_{0}}=(\beta(1+r))^{\frac{1}{\gamma}}\left(\frac{\theta}{r+\delta}\right)\left[\frac{1-\frac{(\beta(1+r))^{\frac{1}{\gamma}}}{1+r}}{1-\left(\frac{(\beta(1+r))^{\frac{1}{\gamma}}}{1+r}\right)^{T+1}}\right]=0.04
$$

\footnotetext{
${ }^{34}$ When $\beta=\sqrt[4]{0.93}$, households are more impatient, and spend more in the short run. For example, the short-run spending response increases from $\$ 75$ when $\beta=\sqrt[4]{1.01}$ to $\$ 118$ when $\beta=\sqrt[4]{0.93}$.
} 
where $\theta$ and $1-\theta$ are the shares of lifetime expenditure devoted to nondurables and durables, respectively. The term $r+\delta$ is a user cost, or the per-period price of durables relative to nondurables, and $\left[\frac{1-\frac{(\beta(1+r))^{\frac{1}{\gamma}}}{1+r}}{1-\left(\frac{(\beta(1+r))^{\frac{1}{\gamma}}}{1+r}\right)^{T+1}}\right]$ is an annuitization factor.

Second, the household purchases large quantities of durables and more modest quantities of nondurables upon learning about the minimum wage hike. The reason for the durables increase is that if the household wishes to permanently increase the service flow of durables by a small amount, it must increase durables spending by a larger amount. After an initial jump, durables spending can decline again as the household only spends to maintain the new higher durables stock (Mankiw 1982).

Third, the spending response occurs when the household learns about a minimum wage hike in quarter -3 , not when the hike occurs in quarter 0 .

The magnitude, composition, and timing of these predictions are inconsistent with the empirical findings described in Section II.

\section{E. Model Results with Borrowing Constraints and Income Uncertainty}

Next, we introduce collateral constraints and income uncertainty to the model. Figure 7 plots the spending response to a minimum wage hike that emerges from this model. It illustrates several noteworthy, and ultimately testable, implications.

The first is the sheer magnitude of the spending increase. Total spending increases by over $\$ 300$ per quarter in the year after the minimum wage hike. This increase in spending is larger than the gain in income in the first year.

The second finding relates to timing. Spending increases when the minimum wage increases, not when the household learns about the impending hike in quarter -3 . Because households are unable to borrow against future income in order to finance current spending, their spending does not rise until the minimum wage increases. Between quarters -1 and 0 , the total spending response increases from $\$-89$ to $\$ 468$.

The third finding has to do with the composition of spending before and after the minimum wage increase. Prior to its implementation but after its legislative enactment (quarters -3 to -1 ), total spending is largely unchanged. Nondurables spending rises while durables spending falls. Once the minimum wage increases in quarter 0 , however, durables spending soars by $\$ 512$ relative to the previous quarter, while nondurables spending continues along a relatively stable path that began at quarter -3 . In the face of borrowing constraints, fluctuation in durables spending is optimal because a short-run decline in durables spending has a small effect on the durables stock and its corresponding service flow. Put simply, it is easier to postpone buying a car than food (see Browning and Crossley 2000 for a proof).

That leads us to our final notable result - the persistence of durables spending. The minimum wage hike increases durables spending by $\$ 363, \$ 227$, and $\$ 135$ during quarters 0,1 , and 2 . The increase in durables spending is still larger than the increase in nondurables two quarters after the minimum wage hike.

One of the striking aspects of this model is that spending exceeds income in the near term. To see the intuition behind this result, and why spending may be 


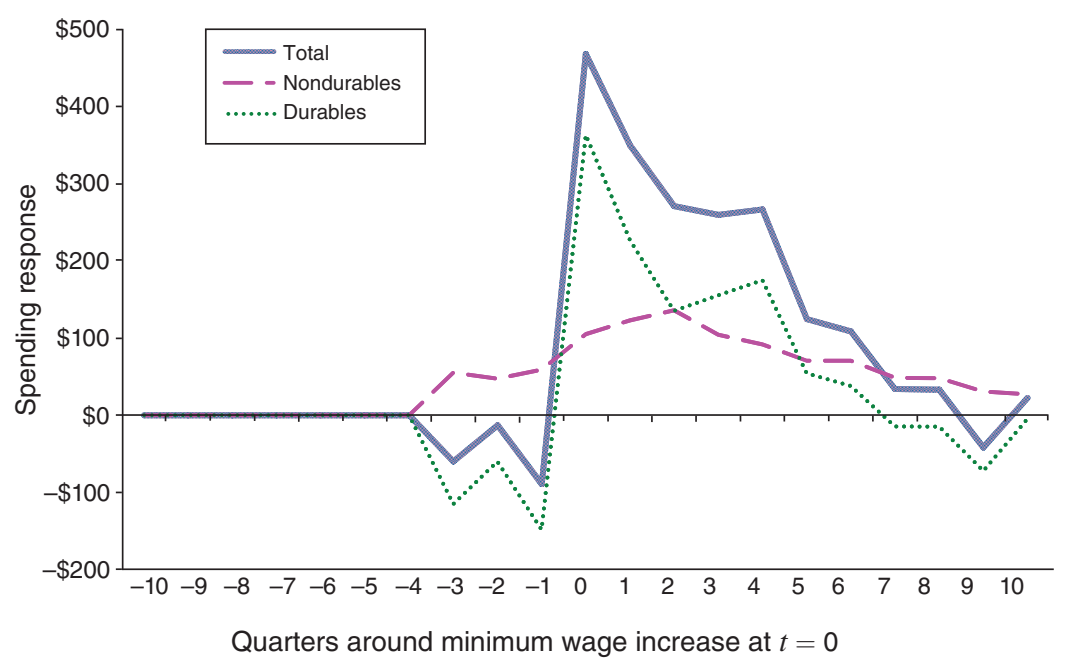

Figure 7. Spending Change around a Minimum Wage Increase Simulation WTH BorRowing CONSTRaints

concentrated in durables expenditures, assume that the borrowing constraint (7) always binds; i.e., $A_{t}=-(1-\pi) D_{t}$. Combining equation (7) with the asset accumulation equation (5) and the law of motion for durables, equation (6), it can be shown that

$$
\pi I_{t}+C_{t}+(1-\pi)(r+\delta) D_{t}=Y_{t}
$$

Households spend income on durables $I_{t}$, nondurables $C_{t}$, and interest payments on durables $D_{t}$. Since the household only needs $\$ \pi$ in income to purchase $\$ 1$ worth of durables, spending gains can temporarily exceed income gains.

The model with borrowing constraints and income uncertainty better matches the magnitude, timing, composition, and persistence of the CEX spending response than the model without these features. Figure 8, panels A-D plot our estimates (solid lines) against the predictions of the model without borrowing constraints (dotted lines) and with borrowing constraints (dashed lines). Figure 8, panel A displays the response of total spending; Figure 8, panel B nondurables; Figure 8, panel C durables; and Figure 8 , panel D debt. ${ }^{35}$ The figure emphasizes that the predicted spending response of the model with borrowing constraints is smaller than that estimated in the data, but is much larger than the response predicted by the model with no borrowing constraints. Furthermore, the timing of the model with borrowing constraints matches up well with what is observed in the data.

\footnotetext{
${ }^{35}$ As above, we assume there is no change in financial assets around minimum wage hikes, so the debt change is $-\Delta A_{t}$.
} 
Panel A. Total spending response to a change in the minimum wage

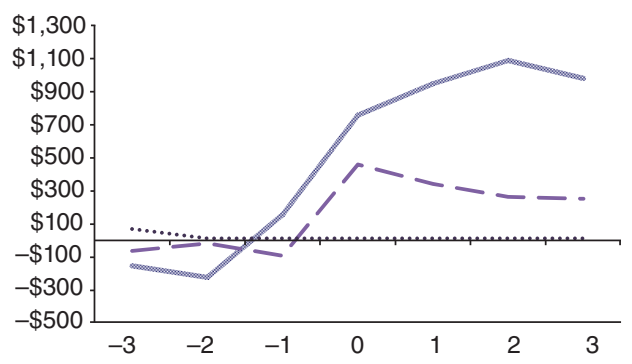

Quarters around minimum wage increase at $t=0$

Panel C. Durables response to a minimum wage change

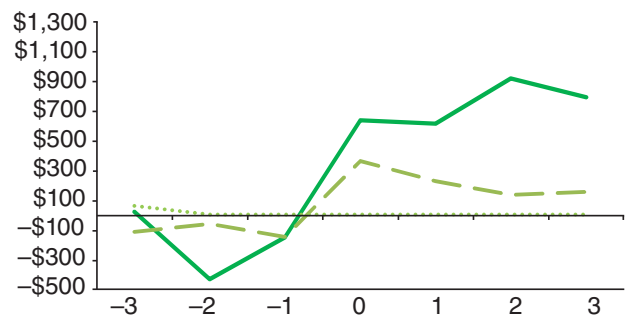

Quarters around minimum wage increase at $t=0$
Panel B. Nondurable response to a minimum wage change

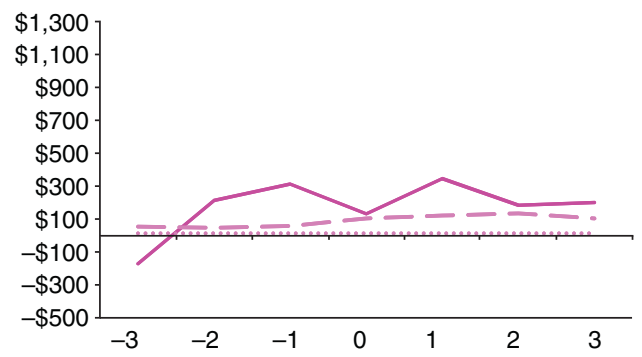

Quarters around minimum wage increase at $t=0$

Panel D. Debt response to a minimum wage change

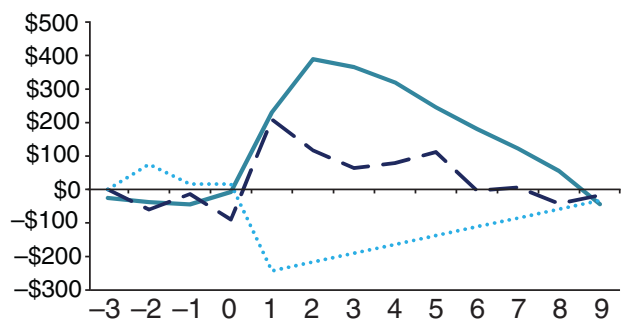

Quarters around minimum wage increase at $t=0$

Figure 8

Notes: Solid lines are data (see Figures 2 and 3). Dashed and dotted lines are model predictions with and without borrowing constraints. See text.

Table 8-Robustness Checks

\begin{tabular}{|c|c|c|c|c|c|}
\hline Parameters & $\begin{array}{l}\text { Nondurables } \\
\text { spending }\end{array}$ & $\begin{array}{l}\text { Durables } \\
\text { spending }\end{array}$ & $\begin{array}{c}\text { Total } \\
\text { spending }\end{array}$ & $\begin{array}{l}\text { 25th percentile } \\
\text { voluntary }^{\text {equity }}\end{array}$ & $\begin{array}{l}\text { Median } \\
\text { voluntary } \\
\text { equity }^{\mathrm{c}}\end{array}$ \\
\hline Estimates $^{\mathrm{a}}$ & -60 & 875 & 815 & -70 & 452 \\
\hline Baseline $^{\mathrm{b}}$ & 57 & 411 & 468 & 0 & 73 \\
\hline$\pi=1.0$ & 28 & 193 & 221 & 0 & 47 \\
\hline$\pi=1.0, \beta=\sqrt[4]{0.95}$ & 18 & 196 & 214 & 0 & 106 \\
\hline$\sigma_{\epsilon}^{2}=0, \beta=\sqrt[4]{0.95}$ & 4 & 616 & 620 & 0 & 0 \\
\hline$\sigma_{\epsilon}^{2}=0.002, \sigma_{u}^{2}=0.0, \beta=\sqrt[4]{0.95}$ & 34 & 415 & 449 & 0 & 67 \\
\hline Adjustment cost $=0.05$ & -16 & 225 & 209 & 173 & 494 \\
\hline Adjustment cost $=0.05, \beta=\sqrt[4]{0.91}$ & -13 & 213 & 201 & 138 & 280 \\
\hline $\begin{array}{l}\beta=1.01, \sigma_{\epsilon}^{2}=0, \text { no borrowing } \\
\quad \text { constraints }\end{array}$ & 3 & 50 & 53 & NA & NA \\
\hline $\begin{array}{l}\beta=1.01, \sigma_{\epsilon}^{2}=0, \text { adjustment } \\
\text { cost }=0.05, \text { no borrowing } \\
\text { constraints }\end{array}$ & -5 & 26 & 21 & NA & NA \\
\hline
\end{tabular}

${ }^{\text {a }}$ Spending estimates from Table 3, voluntary equity from online Appendix Table A4.

${ }^{\mathrm{b}}$ Baseline parameters shown in Table 7. All parameters are set to baseline values unless otherwise indicated.

${ }^{\mathrm{c}}$ Voluntary equity defined as $A_{i t}+(1-\pi) D_{i t}$. 


\section{F. Robustness Checks}

Table 8 describes the robustness of our model predictions to changes in down payment rate and the income process. The particular way parameters are adjusted for each of these tests is explained in the first column. The next three columns report nondurables, durables, and total spending responses to minimum wage hikes given the new parameter values. The fifth and sixth columns report the 25 th and 50 th percentiles of voluntary equity, $A_{i t}+(1-\pi) D_{i t}$, which is a measure of how borrowing constrained the agent is.

The first row reviews our estimated spending response from the CEX and the 25th and 50th percentiles of voluntary equity in the SCF. The second row reviews our baseline borrowing constraint model, as described in Section IIIE and Figure 7. 36 Model predicted total spending rises by $\$ 468$ in total per quarter after a minimum wage hike.

The next row increases the down payment rate to 100 percent, as in the standard buffer stock model with durable goods. The spending response in this case is $\$ 221$ when $\beta=\sqrt[4]{0.93}$, and the response falls slightly to $\$ 214$ when we increase $\beta$ to $\sqrt[4]{0.95}$ to better match the observed distribution of voluntary equity. Higher down payment rates mean fewer durable goods can be purchased with a given level of income. Thus, spending is less sensitive to income when the down payment is higher.

The next two rows explore the sensitivity of the results to differences in the income process. Given that some of the income heterogeneity estimated in Meghir and Pistaferri (2004) or Gourinchas and Parker (2002) may not reflect uncertainty so much as income changes known to individuals, we explore lower levels of income risk than in the benchmark specification.

The spending response is sensitive to the level of income risk. Income risk causes agents to hold precautionary wealth, which in turn affects whether borrowing constraints bind. When borrowing constraints bind, the spending response is larger. For example, when $\sigma_{\epsilon}^{2}=\sigma_{u}^{2}=0.0$ and $\beta=\sqrt[4]{0.95}$ (no income uncertainty and households are impatient), the key saving motive is removed. Median voluntary equity is $\$ 0$. Because agents are borrowing constrained in this scenario, the total spending response rises to $\$ 620$ per quarter. Consistent with the empirical evidence, this response is driven almost entirely by durables. That is, we can replicate the estimated spending responses in the data when we reduce the amount of voluntary equity held by minimum wage households. Although this calibration of the model better matches the spending responses than the baseline specification, it produces lower voluntary equity and thus tighter borrowing constraints than what the SCF data suggest. For this reason, we view our baseline specification where not all minimum wage households are borrowing-constrained as more plausible.

When reducing income uncertainty but holding the distribution of voluntary equity fixed, spending responses are similar to the baseline estimates. Eliminating

\footnotetext{
${ }^{36}$ These are estimated on the simulated data using a household fixed effects regression similar to equation (1). In order to be consistent with the empirical methods and CEX data, we use simulated spending data two quarters before to two quarters after the minimum wage hike. To further match the empirical methodology, we assume the share of minimum wage households that receive minimum wage hikes is similar to that in the data.
} 


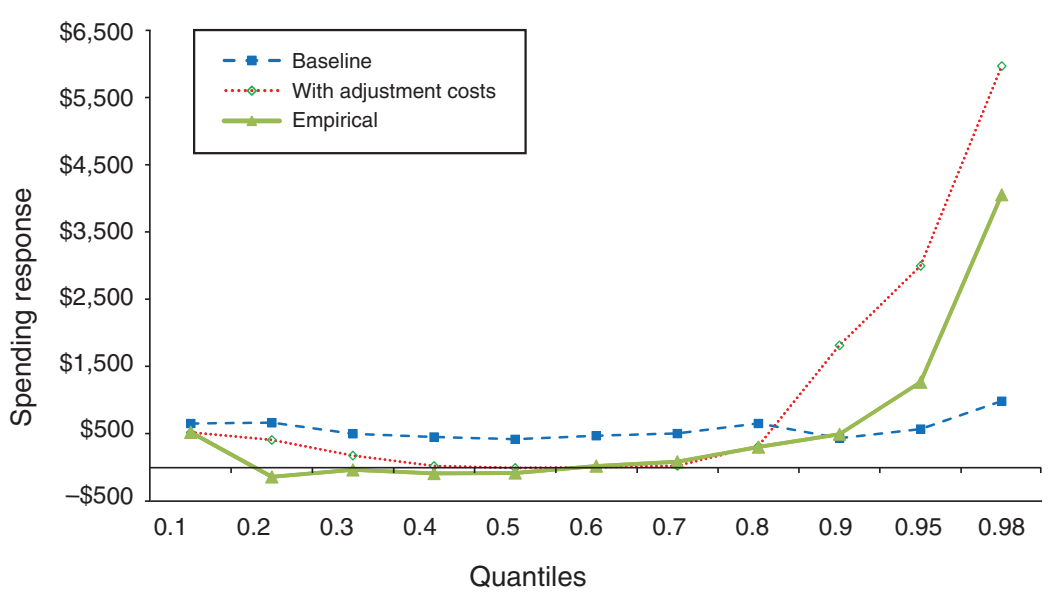

Figure 9. Model Predicted Spending Response to a Change in Minimum Wage With AND Without AdJustment Costs: Quantile Regressions

the variance of transitory income shocks and reducing the variance of persistent shocks so that $\sigma_{\epsilon}^{2}=0.002$ and $\sigma_{u}^{2}=0.0$, but setting $\beta=\sqrt[4]{0.95}$ to keep voluntary equity roughly fixed, leads to a spending response of $\$ 449$. This is similar to the response from the baseline specification.

The next row reports spending responses when there are adjustment costs, which we discuss in greater detail in Section IIIG. For completeness, the final two rows report spending responses in the model without borrowing constraints, as in Section IIID. ${ }^{37}$ As before, spending barely responds under this version of the model.

\section{G. Adjustment Costs and the Distribution of Spending Responses}

Because much of the spending increase comes from vehicles, there is considerable heterogeneity in spending after a minimum wage increase. Figure 9 compares the estimated distribution of the spending response, as shown in Figure 1 and replotted with the solid green line, to that predicted by our baseline model (the dashed blue line), as well as the baseline model augmented for adjustment costs (the dotted red line). The baseline model predicts roughly the same-sized effect throughout the spending distribution and thus underpredicts the spending response at the right tail relative to what is seen in the data.

Now, consider the possibility that households face a cost of adjusting their durables stock, as in Carroll and Dunn (1997) and Kaboski and Townsend (2011). Households might face transactions costs of adjusting their durables stock if the trade-in value of a used car is less than the price of buying the same car from a used car lot. We follow Grossman and LaRoque (1990) and Eberly (1994) by assuming that in order to increase the durables stock, 5 percent of the previous stock would be lost. ${ }^{38}$ Given this assumption, the model predicts that purchases occur every

\footnotetext{
${ }^{37}$ As in Section IIID, we set $\beta=\sqrt[4]{1.01}$ to generate a plausible wealth level.

${ }^{38}$ See also Attanasio (2000) and Bertola, Guiso, and Pistaferri (2005) for more evidence.
} 
12 quarters, which is similar to the frequency of vehicle expenditures in the CEX. This adjustment cost transforms equation (5) into

$$
A_{t+1}=(1+r) A_{t}+Y_{t}-C_{t}-I_{t}-0.05 D_{t} \times I\left\{I_{t} \neq 0\right\},
$$

where $I\left\{I_{t} \neq 0\right\}$ is an indicator for whether the individual purchases or sells a durable good.

When we make this modification, but leave other parameters at the baseline, the average total spending response moves from $\$ 468$ to $\$ 209$ per quarter (see Table 8) when we hold $\beta$ at its baseline level and $\$ 201$ when we reduce $\beta$ to $\sqrt[4]{0.91}$ to better match the distribution of voluntary equity. Thus, the model with adjustment costs does worse at explaining large mean spending responses in the data.

That said, adjustment costs, combined with the borrowing constraint, better explain the skewness of spending responses. This is displayed in the red dotted line in Figure 9 for the case where $\beta=\sqrt[4]{0.91}$. The model with adjustment costs displays a significant spike in spending at the right tail of the spending distribution. In particular, for those at the 98th percentile, the spending response is $\$ 5,966$ per quarter, larger than the $\$ 4,053$ observed in the data.

This higher response comes about because households upgrade their durables stock periodically in the adjustment cost model. Thus, for the majority of households, the durables spending response is zero in any given quarter. Conditional on a minimum wage increase, the probability of a durables purchase, as well as the amount spent conditional on a purchase, rises. This causes the spending response to be very large at the 95th and 98th percentiles but small below that. Consequently, the model with a 5 percent adjustment cost overstates the right tail of the spending distribution, whereas the model without adjustment costs understates it.

\section{Discussion}

In this paper, we estimate the magnitude, timing, composition, and distribution of the income, spending, and debt responses to minimum wage hikes among households with adult minimum wage workers. We present four key empirical findings.

First, a $\$ 1$ minimum wage hike increases total spending by approximately $\$ 700$ per quarter in the near term. This exceeds the roughly $\$ 250$ per-quarter increase in family income following a minimum wage hike of similar size. These patterns are corroborated by independent data showing that debt rises substantially after a minimum wage increase. Second, the majority of this additional spending goes toward durable goods, in particular vehicles. Consequently, the spending response is concentrated among a small number of households. Third, total spending increases within one quarter of a minimum wage increase and not prior, despite legislation typically passing 6 to 18 months before enactment. Finally, high levels of durables spending and debt accumulation persist for several quarters after a minimum wage hike.

We find that the model that best matches these facts is an augmented buffer stock model in which households can borrow against part, but not all, of the value of their durable goods. If households face collateral constraints, small income increases can generate small down payments, which in turn can be used for large durable goods 
purchases. With a 20 percent down payment, each additional dollar of income can be used to purchase $\$ 5$ of durable goods. Consistent with this model, we find that most of the debt increase following a minimum wage hike is in collateralized debt, such as auto loans. Adjustment costs (representing, say, the trade-in cost of a vehicle) can help to reproduce the fact that the spending response is skewed.

While our model goes a good ways toward explaining the spending patterns in the data, it still falls short. One explanation is that borrowing constraints are more widespread than we assume based on observed asset holdings. Indeed, our model can reproduce the estimated spending responses if we assume near-universal borrowing constraints among minimum wage households. ${ }^{39}$ A better understanding of this and other alternative explanations is left for future work.

\section{REFERENCES}

Aaronson, Daniel. 2001. "Price Pass-Through and the Minimum Wage." Review of Economics and Statistics 83 (1): 158-69.

-Aaronson, Daniel, Eric French, and James MacDonald. 2008. "The Minimum Wage, Restaurant Prices, and Labor Market Structure.” Journal of Human Resources 43 (3): 688-720.

Aaronson, Daniel, Sumit Agarwal, and Eric French. 2012. "The Spending and Debt Response to Minimum Wage Hikes: Dataset.” American Economic Review. http://dx.doi.org/10.1257/aer.102.7.3111.

-Adams, William, Liran Einav, and Jonathan Levin. 2009. "Liquidity Constraints and Imperfect Information in Subprime Lending." American Economic Review 99 (1): 49-84.

Adda, Jerome, and Russell Cooper. 2000. "Balladurette and Juppette: A Discrete Analysis of Scrapping Subsidies." Journal of Political Economy 108 (4): 778-806.

Addison, John, McKinley Blackburn, and Chad Cotti. 2008. "The Effect of Minimum Wages on Labor Market Outcomes: County-Level Estimates from the Restaurant-and-Bar Sector.” Unpublished.

-Attanasio, Orazio P. 2000. "Consumer Durables and Inertial Behaviour: Estimation and Aggregation of (S, s) Rules for Automobile Purchases.” Review of Economic Studies 67 (4): 667-96.

Attanasio, Orazio, Andrew Leicester, and Matthew Wakefield. 2011. "Do House Prices Drive Consumption Growth? The Coincident Cycles of House Prices and Consumption in the UK." Journal of the European Economic Association 9 (3): 399-435.

Barrow, Lisa, and Leslie McGranahan. 2000. "The Effects of the Earned Income Credit on the Seasonality of Household Expenditures." National Tax Journal 53 (4): 1211-43.

Bertola, Giuseppe, Luigi Guiso, and Luigi Pistaferri. 2005. "Uncertainty and Consumer Durables Adjustment." Review of Economic Studies 72 (4): 973-1007.

Browning, Martin, and M. Dolores Collado. 2001. "The Response of Expenditures to Anticipated Income Changes: Panel Data Estimates.” American Economic Review 91 (3): 681-92.

Browning, Martin, and Thomas F. Crossley. 2000. "Luxuries Are Easier to Postpone: A Proof." Journal of Political Economy 108 (5): 1022-26.

Browning, Martin, and Thomas F. Crossley. 2009. "Shocks, Stocks, and Socks: Smoothing Consumption over a Temporary Income Loss." Journal of the European Economic Association 7 (6): 1169-92.

Campbell, Jeffrey R., and Zvi Hercowitz. 2003. “The Dynamics of Work and Debt.” Federal Reserve Bank of Chicago Working Paper WP-04-05.

Card, David Edward, and Alan B. Krueger. 1995. Myth and Measurement: The New Economics of the Minimum Wage. Princeton, NJ: Princeton University Press.

Carrington, William J., and Bruce C. Fallick. 2001. "Do Some Workers Have Minimum Wage Careers?" Monthly Labor Review 124 (5): 17-27.

\footnotetext{
${ }^{39}$ Alternatively, our model might miss an important incentive that people face. For example, minimum wage hikes cause the wage, and thus the price of time, to rise. Although we find no evidence that the minimum wage affects adult hours or employment, a higher minimum wage may cause workers to purchase cars so that they can ensure that they hold on to their job. See Gurley and Bruce (2005), who cite evidence on the importance of access to cars on the probability of work among low-income households.
} 
Carroll, Christopher D., and Wendy E. Dunn. 1997. "Unemployment Expectations, Jumping (S, s) Triggers, and Household Balance Sheets." In NBER Macroeconomics Annual 1997, edited by Ben S. Bernanke and Julio J. Rotemberg, 165-217. Cambridge, MA: MIT Press.

Cerletti, Enzo A., and Josep Pijoan-Mas. 2012. "Durable Goods, Borrowing Constraints and Consumption Insurance.” Unpublished.

Coulibaly, Brahima, and Geng Li. 2006. "Do Homeowners Increase Consumption after the Last Mortgage Payment? An Alternative Test of the Permanent Income Hypothesis." Review of Economics and Statistics 88 (1): 10-19.

Draca, Mirko, Stephen Machin, and John Van Reenen. 2011. "Minimum Wages and Firm Profitability." American Economic Journal: Applied Economics 3 (1): 129-51.

Eberly, Janice C. 1994. "Adjustment of Consumers' Durables Stocks: Evidence from Automobile Purchases." Journal of Political Economy 102 (3): 403-36.

-Fernandez-Villaverde, Jesús, and Dirk Krueger. 2011. "Consumption and Saving over the Life Cycle: How Important Are Consumer Durables?” Macroeconomic Dynamics 15 (5): 725-70.

French, Eric, Bhashkar Mazumder, and Christopher Taber. 2006. "The Changing Pattern of Wage Growth for Low-Skilled Workers.” In Working and Poor: How Economic and Policy Changes Are Affecting Low-Wage Workers, edited by Rebecca M. Blank, Sheldon H. Danziger, and Robert F. Schoeni, 141-72. New York: Russell Sage Foundation.

Gourinchas, Pierre-Olivier, and Jonathan A. Parker. 2002. "Consumption over the Life Cycle." Econometrica 70 (1): 47-89.

Grossman, Sanford J., and Guy LaRoque. 1990. "Asset Pricing and Optimal Portfolio Choice in the Presence of Illiquid Durable Consumption Goods." Econometrica 58 (1): 25-51.

Gurley, Tami, and Donald Bruce. 2005. "The Effects of Car Access on Employment Outcomes for Welfare Recipients." Journal of Urban Economics 58 (2): 250-72.

Hryshko, Dmytro, Maria Jose Luengo-Prado, and Bent E. Sorensen. 2010. "House Prices and Risk Sharing." Journal of Monetary Economics 57 (8): 975-87.

Hsieh, Chang-Tai. 2003. "Do Consumers React to Anticipated Income Changes? Evidence from the Alaska Permanent Fund." American Economic Review 93 (1): 397-405.

-Johnson, David S., Jonathan A. Parker, and Nicholas S. Souleles. 2006. "Household Expenditure and the Income Tax Rebates of 2001.” American Economic Review 96 (5): 1589-1610.

Kaboski, Joseph P., and Robert M. Townsend. 2011. "A Structural Evaluation of a Large-Scale QuasiExperimental Microfinance Initiative.” Econometrica 79 (5): 1357-1406.

Kaplan, Greg, and Giovanni L. Violante. 2010. "How Much Consumption Insurance beyond SelfInsurance?” American Economic Journal: Macroeconomics 2 (4): 53-87.

Kiyotaki, Nobuhiro, and John Moore. 1997. "Credit Cycles.” Journal of Political Economy 105 (2): 211-48.

Krueger, Dirk, and Fabrizio Perri. 2008. "How Do Households Respond to Income Shocks? Evidence, Theory, and Implications." Unpublished.

Lee, David S. 1999. "Wage Inequality in the United States during the 1980s: Rising Dispersion or Falling Minimum Wage?” Quarterly Journal of Economics 114 (3): 977-1023.

Leininger, Lindsey, Helen Levy, and Diane Schanzenbach. 2010. "Consequences of SCHIP Expansions for Household Well-Being." Forum for Health Economics and Policy 13 (1).

Mankiw, N. Gregory. 1982. "Hall's Consumption Hypothesis and Durable Goods." Journal of Monetary Economics 10 (3): 417-25.

Meghir, Costas, and Luigi Pistaferri. 2004. "Income Variance Dynamics and Heterogeneity." Econometrica 72 (1): 1-32.

Neumark, David, Mark Schweitzer, and William Wascher. 2004. "Minimum Wage Effects throughout the Wage Distribution." Journal of Human Resources 39 (2): 425-50.

Neumark, David, Mark Schweitzer, and William Wascher. 2005. “The Effects of Minimum Wages on the Distribution of Family Incomes: A Nonparametric Analysis." Journal of Human Resources 40 (4): 867-94.

Parker, Jonathan A. 1999. "The Reaction of Household Consumption to Predictable Changes in Social Security Taxes." American Economic Review 89 (4): 959-73.

Parker, Jonathan, Nicholas Souleles, David Johnson, and Robert McClelland. 2010. “Consumer Spending and the Economic Stimulus Payments of 2008." Unpublished.

-Smith, Ralph E., and Bruce Vavrichek. 1992. "The Wage Mobility of Minimum Wage Workers." Industrial and Labor Relations Review 46 (1): 82-88.

-Souleles, Nicholas S. 1999. "The Response of Household Consumption to Income Tax Refunds." American Economic Review 89 (4): 947-58.

Wellington, Alison J. 1991. "Effects of the Minimum Wage on the Employment Status of Youths: An Update.” Journal of Human Resources 26 (1): 27-46. 